\title{
Hypoxia Promotes Danger-mediated Inflammation via Receptor for Advanced Glycation End Products in Cystic Fibrosis
}

\author{
Rossana G. Iannitti ${ }^{1}$, Andrea Casagrande ${ }^{1,2}$, Antonella De Luca ${ }^{1}$, Cristina Cunha ${ }^{1}$, Guglielmo Sorci ${ }^{1}$, Francesca Riuzzi ${ }^{1}$, \\ Monica Borghi ${ }^{1}$, Claudia Galosi ${ }^{1}$, Cristina Massi-Benedetti ${ }^{1}$, Tim D. Oury ${ }^{3}$, Lisa Cariani ${ }^{4}$, Maria Russo ${ }^{4}$, Luigi Porcaro ${ }^{4}$, \\ Carla Colombo ${ }^{4}$, Fabio Majo ${ }^{5}$, Vincenzina Lucidi ${ }^{5}$, Ersilia Fiscarelli6, Gabriella Ricciotti ${ }^{6}$, Cornelia Lass-Flörl7, \\ Luigi Ratclif8, Antonella Esposito9, Fernando Maria De Benedictis ${ }^{10}$, Rosario Donato ${ }^{1}$, Agostinho Carvalho', \\ and Luigina Romani ${ }^{1}$

\begin{abstract}
${ }^{1}$ Department of Experimental Medicine and Biochemical Sciences, University of Perugia, Perugia, Italy; ${ }^{2}$ Istituto Superiore di Sanità, Roma, Italy; ${ }^{3}$ Department of Pathology, University of Pittsburgh School of Medicine, Pittsburgh, Pennsylvania; ${ }^{4}$ Fondazione IRCCS Ca' Granda, Ospedale Maggiore Policlinico, University of Milan, Milan, Italy; ${ }^{5}$ Unit of Endocrinology and Diabetes, Bambino Gesù Children's Hospital, Rome, Italy; ${ }^{6}$ Children's Hospital Bambino Gesù IRCCS, Rome, Italy; ${ }^{7}$ Division of Hygiene and Medical Microbiology, Innsbruck Medical University, Innsbruck, Austria; ${ }^{8}$ Servizio di Supporto Fibrosi Cistica, Istituto Ospedale G. Tatarella, Cerignola, Foggia, Italy; ${ }^{9}$ Blood Transfusion Service, Foligno Hospital, Perugia, Italy; and ${ }^{10}$ Department of Mother and Child Health, Salesi Children's Hospital, Ancona, Italy
\end{abstract}

Rationale: Hypoxia regulates the inflammatory-antiinflammatory balance by the receptor for advanced glycation end products (RAGE), a versatile sensor of damage-associated molecular patterns. The multiligand nature of RAGE places this receptor in the midst of chronic inflammatory diseases.

Objectives: To characterize the impact of the hypoxia-RAGE pathway on pathogenic airway inflammation preventing effective pathogen clearance in cystic fibrosis (CF) and elucidate the potential role of this danger signal in pathogenesis and therapy of lung inflammation.

Methods: We used in vivo and in vitro models to study the impact of hypoxia on RAGE expression and activity in human and murine $C F$, the nature of the RAGE ligand, and the impact of RAGE on lung inflammation and antimicrobial resistance in fungal and bacterial pneumonia.

Measurements and Main Results: Sustained expression of RAGE and its ligand $\mathrm{S} 100 \mathrm{~B}$ was observed in murine lung and human epithelial cells and exerted a proximal role in promoting inflammation in murine and human $C F$, as revealed by functional studies and analysis of the genetic variability of $A G E R$ in patients with CF. Both hypoxia and infections

(Received in original form May 30, 2013; accepted in final form October 6, 2013)

Supported by the Italian Grant funded by the Italian Cystic Fibrosis Research Foundation (Research Project number FFC\#16/2012 to L. Romani), the Specific Targeted Research Project ALLFUN (FP7-HEALTH-2010-260338 to L. Romani), and FunMeta (ERC-2011-AdG-293714 to L. Romani). R.G.I. gratefully acknowledges a fellowship from the Italian Cystic Fibrosis Research Foundation. C. Cunha was financially supported by fellowship from Fundação para a Ciência e Tecnologia, Portugal (contract SFRH/BD/65962/2009).

Author Contributions: R.G.I. performed most in vivo murine experiments and analyzed and interpreted data. A. Carvalho and C. Cunha supervised and performed with C.G. the genotypic analysis on human cells. A.D.L. and M.B. contributed to the mouse infection and challenge experiments. A. Casagrande, F.R., and G.S. performed Western blots and immunohistochemistry. C.M.-B. analyzed and scored the histopathology samples. T.D.O. provided reagents and scientific advice. L.C., M.R., and G.R. performed microbiology in clinical samples. L.P. and C.L.-F. performed genotyping. C. Colombo, V.L., F.M., L. Ratclif, C.L.-F., E.F., A.E., and F.M.D.B. provided the clinical samples and conceptual advice. R.D. provided conceptual advice. R.G.I., A. Carvalho, and L. Romani designed the experiments, analyzed data, and wrote the paper. Correspondence and requests for reprints should be addressed to Luigina Romani, M.D., Ph.D., Department of Experimental Medicine and Biochemical Sciences, University of Perugia, Polo Unico Sant'Andrea delle Fratte, 06132 Perugia, Italy. E-mail: luigina.romani@unipg.it

This article has an online supplement, which is accessible from this issue's table of contents at www.atsjournals.org

Am J Respir Crit Care Med Vol 188, Iss. 11, pp 1338-1350, Dec 1, 2013 Copyright $\odot 2013$ by the American Thoracic Society

Originally Published in Press as DOI: 10.1164/rccm.201305-0986OC on October 15, 2013 Internet address: www.atsjournals.org

\section{AT A GLANCE COMMENTARY}

Scientific Knowledge on the Subject

An exaggerated and ineffective airway inflammation that fails to eradicate pulmonary pathogens is present in cystic fibrosis (CF). Thus, deciphering the cellular and molecular pathways leading to chronic inflammation could lead to preventive antiinflammatory strategies in CF. Hypoxia affects the inflammatoryantiinflammatory balance by up-regulating the receptor for advanced glycation end products (RAGE), a versatile sensor of damage-associated molecular patterns. The multiligand nature of RAGE places this receptor in the midst of chronic lung inflammatory diseases.

What This Study Adds to the Field

This study causally links the hyperactivation of RAGE by hypoxia and the RAGE ligand S100B by infections to inflammation in murine and human $\mathrm{CF}$, thus providing a unifying conceptual framework within which to accommodate the vicious cycle of airways infection and inflammation in CF. Targeting pathogenic inflammation by administration of soluble RAGE alleviated inflammation in murine $\mathrm{CF}$, whereas measurement of soluble RAGE levels could predict RAGEdependent inflammation in patients with CF.

contributed to the sustained activation of the S100B-RAGE pathway, being RAGE up-regulated by hypoxia and S100B by infection by Tolllike receptors. Inhibiting the RAGE pathway in vivo with soluble (s) RAGE reduced pathogen load and inflammation in experimental CF, whereas SRAGE production was defective in patients with CF.

Conclusions: A causal link between hyperactivation of RAGE and inflammation in CF has been observed, such that targeting pathogenic inflammation alleviated inflammation in CF and measurement of sRAGE levels could be a useful biomarker for RAGE-dependent inflammation in patients with CF.

Keywords: hypoxia; inflammation; rage; cystic fibrosis; infections

In patients with cystic fibrosis $(\mathrm{CF})$, lung disease is the major cause of morbidity and mortality $(1,2)$. The progressive decline of pulmonary function is caused by a vicious cycle of airways infection and inflammation. The pulmonary immune response 
in $\mathrm{CF}$ is characterized by an early and nonresolving activation of the innate immune system, which is dysregulated at several levels (3), does not result in enhanced bacterial clearance (4), and plays a pivotal role in the pathogenesis of lung disease in CF (5). This is supported by several studies that have documented an altered balance of inflammatory and antiinflammatory cytokines in $\mathrm{CF}$ (6), such that targeting specific inflammatory and antiinflammatory pathways may represent a valid therapeutic strategy in $\operatorname{CF}(7,8)$.

Development of airways hypoxia is a severe complication in patients with $\mathrm{CF}(9,10)$ in which the $\mathrm{CF}$ transmembrane conductance regulator (CFTR) further stabilizes the hypoxia-inducible factor (HIF)-1 $\alpha$ (11). Cell adaptation to low oxygen levels occurs by changing the transcription and translation of certain genes (12), mainly the HIFs family genes, which are stabilized by hypoxia (13). HIF-1 exists as a heterodimer, consisting of HIF- $1 \alpha$ and HIF-1 $\beta$ subunits. HIF-1 $\beta$ is ubiquitously expressed, whereas HIF- $1 \alpha$ is found at very low levels under normoxic conditions because of active proteasomal degradation; however, acute exposure to hypoxia ( $\leqslant 1 \%$ oxygen) causes increased HIF- $1 \alpha$ protein levels and HIF- $1 \alpha$ DNA-binding activity (14). HIF-1 $\alpha$ is not only a key mediator of adaptation to hypoxia but is also heavily involved in inflammation (15) and T-cell differentiation $(16,17)$, through its regulation of the metabolic switch to glycolysis, a switch that is intrinsic to myeloid and T-cell survival and function. Thus, HIF-1 $\alpha$ promotes Th17 differentiation $(16,17)$, a finding consistent with the reduction of indoleamine 2,3-dioxygenase (IDO) and IFN- $\gamma$ activities under hypoxia $(18,19)$. However, hypoxia is also an evolutionary mechanism aimed to guarantee tissue homeostasis by innate mechanisms while avoiding autoimmunity (20). Thus, it is not surprising that hypoxia enhanced $\mathrm{FoxP}^{+}$regulatory $\mathrm{T}$-cells abundance and function to limit tissue damage in conditions of reduced oxygen availability (21). These data indicate that a better understanding of the molecular pathophysiology of hypoxia in CF might lead to strategies for the prevention and/or treatment of hypoxia-mediated lung complications.

One interesting mechanism by which hypoxia may regulate the inflammatory-antiinflammatory balance is the induction of expression of the receptor for advanced glycation end products (RAGE), a versatile sensor of damage-associated molecular patterns (22), that is expressed at high levels in the lung (23) where it plays a major role in both homeostasis and pathology (24). Genome-wide association studies have shown that variants of $A G E R$, the gene encoding RAGE, are correlated with lung disease in patients with $(25,26)$ and without $(27,28) \mathrm{CF}$. RAGE is a membrane receptor capable of activating several proinflammatory signaling pathways on binding to different ligands (29). It also has an inhibitory decoy receptor, the soluble (s) RAGE, the deficiency of which is linked to heightened inflammation in various chronic pulmonary diseases (30), whereas its administration showed therapeutic potential in lung injury (31). Thus, RAGE contributes to lung diseases such that measurement of sRAGE levels could be a useful biomarker for RAGEdependent pathology in the lung (32-34), whereas targeting RAGE signaling is likely to be important in the therapeutic alleviation of lung injury and associated persistent inflammation.

In this study, we tested the hypothesis that hypoxia may contribute to RAGE-dependent lung pathology in CF. Specifically, we assessed whether hypoxia is an up-stream regulator of RAGE in experimental and clinical $\mathrm{CF}$ and whether targeting hypoxia and/or RAGE is a drugable strategy in CF. We resorted to Cftr tm1 $\operatorname{Unc}\left(\mathrm{Cftr}^{-1-}\right)$ mice, reported to mimic, to some extent, human $\mathrm{CF}$ (7) and patients with CF to verify that hypoxia may lead to unopposed RAGE activation in response to Aspergillus fumigatus, a common pathogen in CF (35), to the pathogenesis of which adaptation to hypoxia (36) and hyperfunction of RAGE contribute both in mice (37) and humans (38). We also evaluated RAGE activation in infection by Pseudomonas aeruginosa that, of interest, is known to induce HIF-1 $\alpha$ stabilization (39). We demonstrated that RAGE is up-regulated in murine and human CF by hypoxia and is associated with lung disease severity in infections. The hypoxic pathway does not operate in isolation, but rather in concert with the Toll-like receptor (TLR) promoting the production of S100B, an EF-hand (i.e., two helix-loop-helix motifs) calcium-binding protein that acts through RAGE (40). We also obtained a proof-of-concept demonstration that targeting the hypoxia-RAGE pathway in vivo restored effective inflammation and pathogen clearance in the lung.

\section{METHODS}

\section{Animals}

Six- to eight-week C57BL/6 mice were purchased from Charles River (Calco, Italy). Genetically engineered homozygote $\mathrm{Cftr}^{-/-}$mice (7) were bred at the CF core animal facility at San Raffaele Hospital, Milan. Experiments were performed according to the Italian Approved Animal Welfare Assurance 245-2011-B.

\section{Aspergillus fumigatus Infection}

Mice were anesthetized by intraperitoneal injection of $2.5 \%$ avertin (Sigma Chemical, St. Louis, MO) before intranasal instillation of $2 \times 10^{7}$ resting conidia per $20 \mu \mathrm{l}$ saline of A. fumigatus (AF 293), Aspergillus terreus, Aspergillus nidulans, or A. fumigatus (AF 300) and its mutant (AF 300niaD7, hereafter referred as AF 300 mutant) unable to grow in hypoxic conditions (41). For histology, paraffin-embedded tissue was stained with periodic acid-Schiff and bronchoalveolar lavage fluid collection was done as described (7).

\section{Pseudomonas aeruginosa Chronic Infection}

A mucoid strain isolated from a patient with CF (42) was embedded in agar beads, as described (43). Twenty microliters of the agarose bead suspension (containing $2 \times 10^{6} \mathrm{P}$. aeruginosa $\mathrm{cfu}$ ) was injected into the trachea with a 26-gauge needle and a small syringe into anesthetized mice.

\section{Treatments}

Mice were treated intranasally with $20 \mu \mathrm{g}$ of sRAGE every other day, starting the day before and up to 7 (A. fumigatus infection) or 13 ( $P$. aeruginosa infection) days after the infection. Additional details are reported in the online supplement.

\section{Hypoxyprobe Treatment}

Mice were intravenously injected with hypoxyprobe at a dose of $60 \mathrm{mg} / \mathrm{kg}$ weight of the mouse (Hypoxyprobe Inc., Burlington, MA). After 60 minutes, mice were killed and the lung of each mouse was filled with an embedding medium used for frozen tissue to ensure optimal cutting temperature (OCT) and after embedding in OCT immediately frozen in liquid nitrogen. Additional details are reported in the online supplement.

\section{Western Blotting}

Blots of lung lysates were incubated with primary antibodies followed by appropriate antimouse or antirabbit secondary horseradish peroxidaselinked antibody (Cell Signaling). Blots were developed with the LiteABlot Plus Chemiluminescence detection kit (Euroclone, Milan, Italy). Further details are in the online supplement.

\section{ELISA Assays}

ELISA for sRAGE was performed using the Quantikine Human RAGE Immunoassay kit (R\&D Systems, Minneapolis, MN). For S100B ELISA, human S100B ELISA KIT (Millipore, Billerica, MA) was used following manufacturer's instructions.

\section{Immunohistochemistry}

Lung sections were incubated overnight with polyclonal anti-S100B antibody (1:100) or polyclonal anti-RAGE antibody followed by the secondary antibodies (i.e., horseradish peroxidase-conjugated goat antirabbit IgG 
[Sigma-Aldrich, St. Louis, MO] for S100B, and AlexaFluor 594 donkey antigoat IgG [Invitrogen, Monza MB, Italy] for RAGE). Cells were counterstained with hematoxylin or DAPI (4,6- diamidino-2-phenylindole). Endogenous peroxidase activity was quenched using $3 \% \mathrm{H}_{2} \mathrm{O}_{2}$ in phosphate-buffered saline. Fluorescence and immunofluorescence microscopy was performed on an Olympus (Segrate, Italy) microscope (BX51) and analySIS image processing software.

\section{Human Bronchial Epithelial Cells}

Human bronchial epithelial (HBE) cells homozygous for the $\delta$ F508 mutation were obtained from lung transplants (patients with $\mathrm{CF}$ ) or lung resections (patients without $\mathrm{CF}$ ) and cultured as described (44). For growth conditions and treatment, see the Methods section in the online supplement.

\section{Statistical Analysis}

Results are expressed as means \pm SD. Statistical analysis was performed with Student $t$ test or one-way analysis of variance Bonferroni post-test and analyzed by GraphPad Prism 4.03 program (GraphPad Software, San Diego, CA). Values of $P$ less than or equal to 0.05 were considered significant.

\section{RESULTS}

\section{RAGE and S100B Expressions Are Up-regulated in CF Mice with Aspergillosis}

RAGE is expressed on epithelial and myeloid lung cells of C57BL/6 (wild-type [WT]) mice with aspergillosis (37). We assessed the expression of RAGE gene and protein in the lungs of $A$. fumigatusinfected CF mice by immunofluorescence staining, Western blotting, and reverse transcriptase polymerase chain reaction. RAGE expression was observed at protein (Figure 1A) and mRNA (Figure 1B) levels in uninfected WT and, more, CF mice; it maximally occurred, and remained elevated thereafter, at 7 days postinfection in $\mathrm{CF}$ mice, a time at which it returned to baseline levels in WT mice (Figures 1A and 1B). Multiple RAGE isoforms arise through alternative splicing and/or proteolysis in the different mouse organs (45). Mouse lung expresses three major RAGE isoforms of $57.4,52.6$, and $45.1 \mathrm{kD}$ recognized by N-16 antibody: (1) the xRAGE, likely an additional form of membrane RAGE; (2) the "full-length" transmembrane isoform (mRAGE), and (3) a soluble (sRAGE) isoform $(45,46)$. All three isoforms were present in the lung of WT and CF mice (Figure 1C). Interestingly, sRAGE increased during infection in WT mice but apparently failed to do so in CF mice, particularly at 7 days postinfection when sRAGE could not be detected. RAGE expression in CF mice was associated with signs of RAGE activation, as indicated by the sustained levels of ERK p42/p44 phosphorylation (Figure 1D) and canonical nuclear factor (NF)-кB (p-IKK $\beta$ ) activation (Figure 1E), both pathways known to occur downstream RAGE (47). Both pathways were apparently down-regulated, as a result of RAGE inhibition (37), in WT mice in which noncanonical NF- $\mathrm{B}(\mathrm{p}-\mathrm{IKK} \alpha)$ activation (Figure 1E) and p38 phosphorylation (Figure $1 \mathrm{~F}$ ) were instead progressively increasing.

On assessing which putative ligands of RAGE were concomitantly expressed in CF, we looked for high-mobility group box 1 (HMGB1) and S100B, a member of the S100-calgranulin family, expression in the lung during infection. We found that the kinetics of HMGB1 gene (Figure $1 \mathrm{G}$ ) and protein (Figure $1 \mathrm{H}$ ) expression was similar in $\mathrm{CF}$ and WT mice. In contrast, S100B gene (Figure 1G) and protein (Figure 1I) expression was not only higher in CF than WT mice at the basal level but continued to be elevated in $\mathrm{CF}$ mice throughout the infection as opposed to WT mice. Indeed, immunohistochemistry showed that, in CF mice, S100B immunereactivity was high and sustained in bronchiolar epithelial cells, known to be major sources of S100B in infection (37), but also in infiltrating inflammatory cells (Figure 1I). These data suggest that although HMGB1 and S100B pairs with RAGE very early in infection in either type of mice, a sustained S100B-RAGE expression only occurs in $\mathrm{CF}$ mice.

\section{Hypoxia Regulates RAGE Expression in CF Mice}

The ability of HIF-1 $\alpha$ to bind to the RAGE promoter and transcriptionally activate it (22) is responsible for the increased expression of RAGE in ischemic hypoxia (48). To determine whether the HIF-1 $\alpha-$ RAGE pathway is active in CF, we first visualized hypoxia in vivo by immunofluorescence with the hypoxia marker, pimonidazole hydrochloride $(22,49)$, and measured HIF-1 gene and protein expression levels in CF mice with aspergillosis. The amount and extent of hypoxia was significantly increased in CF mice because it could be detected in the lungs of uninfected mice and in lesions (red) throughout the course of the infection (Figure 2A). In terms of HIF-1 gene expression, HIF- $1 \alpha$, but not HIF-1 $\beta$, gene was up-regulated early in infection in either type of mice to return to baseline levels a week after the infection in WT but not CF mice in which HIF-1 $\alpha$ mRNA (Figure 2B) and protein (Figure 2C) maintained elevation. This up-regulation of Hifla mRNA was mirrored by similar changes in the mRNA levels of the HIF-1 $\alpha-$ dependent glycolytic genes (50), such as the transporters glucose transport 1 (Glut1), pyruvate kinase $(P K)$, and lactate dehydrogenase $(L d h-\alpha)$ (Figure 2D).

We next assessed whether blocking HIF-1 $\alpha$ affects RAGE expression, infection, and inflammation. To this purpose, WT and $\mathrm{CF}$ mice were infected and concomitantly subjected to HIF- $1 \alpha$ blocking by means of delivery of specific siRNA into the lung. Treatment with HIF-1 $\alpha$ siRNA, which per se reduced HIF-1 $\alpha$ gene and protein expression (see Figures E1A and E1B in the online supplement), reduced RAGE protein expression in the lungs of infected mice (Figure 3A). Of interest, all the isoforms decreased in WT mice but not in CF mice in which sRAGE actually increased (Figure 3B), a finding suggesting that HIF-1 $\alpha$ differently affects the expression of the RAGE isoforms in infection. Treatment was associated with a divergent effect in WT versus $\mathrm{CF}$ mice. It decreased the ability to control infection and inflammation in WT mice, as evidenced by the increased fungal burden (Figure 3C), tissue inflammation (Figure 3D), inflammatory cytokine (tumor necrosis factor- $\alpha$ and IL-17A) production, and decreased IL-10 (Figure 3E). Opposite results were obtained in $\mathrm{CF}$ mice in which fungal growth restriction (Figure 3C), amelioration of tissue inflammatory pathology (Figure 3D), and increased IL-10 over proinflammatory cytokine production (Figure 3E) were observed on HIF-1 $\alpha$ inhibition. Confirming the Western blotting data, sRAGE production in CF mice was increased by the treatment (Figure 3E). Finally, consistent with the asthma exacerbation by hypoxia (51), blocking HIF-1 $\alpha$ decreased IL-4 and IL-13 production in CF mice (Figure 3E). These results indicate that the sustained activation of the HIF-1 $\alpha-$ RAGE pathway in $\mathrm{CF}$ in response to hypoxic stress results in pathogenic inflammatory and allergic responses. In contrast, consistent with ability of the RAGE axis to restrain pathogen-induced inflammation in WT mice (37), blockade of the HIF-1 $\alpha-$ RAGE pathway may impair the host ability to control infection and inflammation in physiologic conditions.

\section{Infection Contributes to the S100B-RAGE Up-regulated Expression by TLRs}

The above findings indicate that RAGE is under the transcriptional control of HIF- $1 \alpha$ in $\mathrm{CF}$, but how S100B production is regulated during infection is not clear. Specific binding sites for $\mathrm{NF}-\kappa \mathrm{B}$ family members exist in the promoter of both human 
A dpi 0
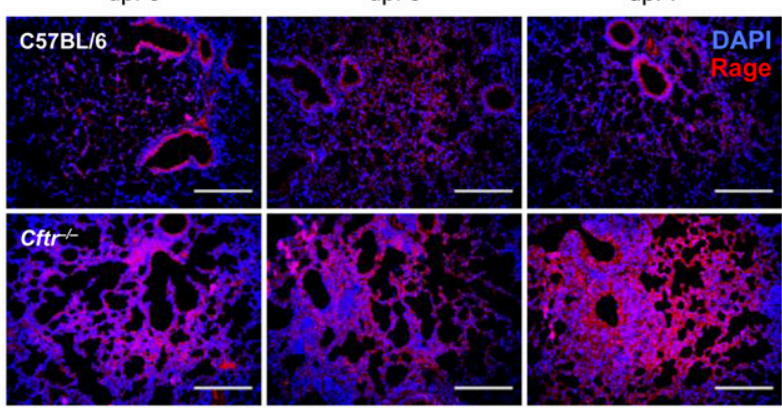

B

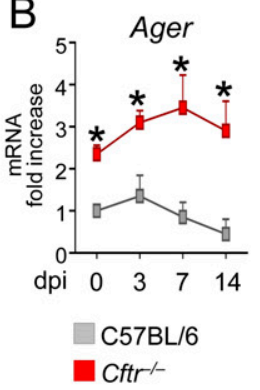

D

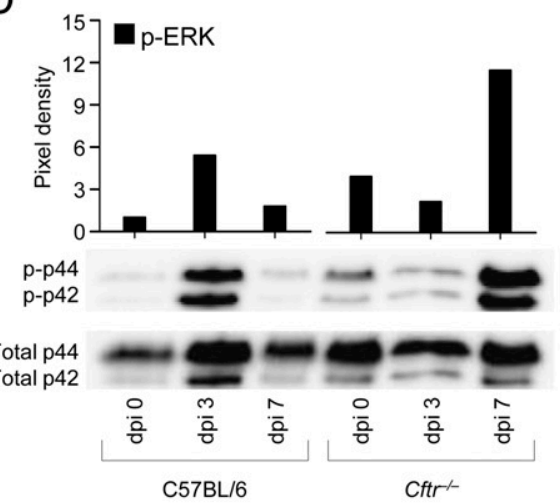

E

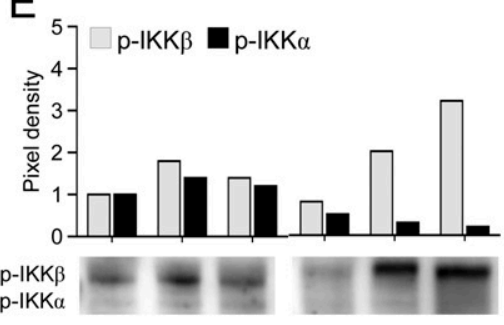

$\beta$-tub $=-$ Total p38

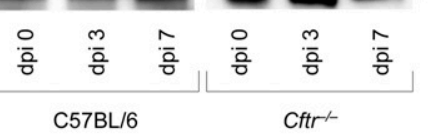

C

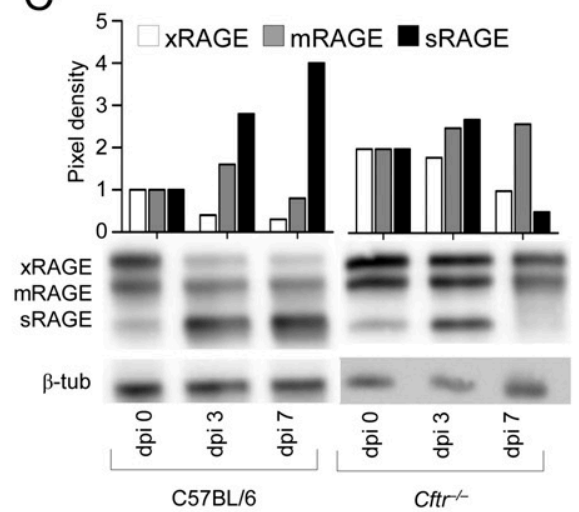

$\mathrm{F}$

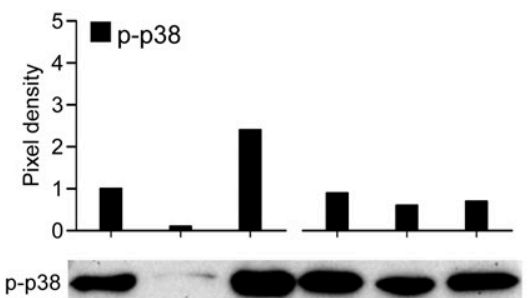

G
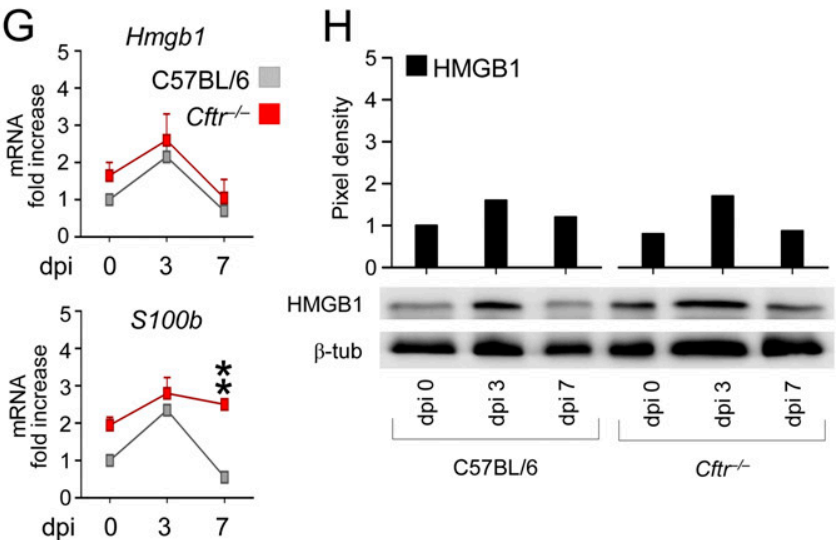

I

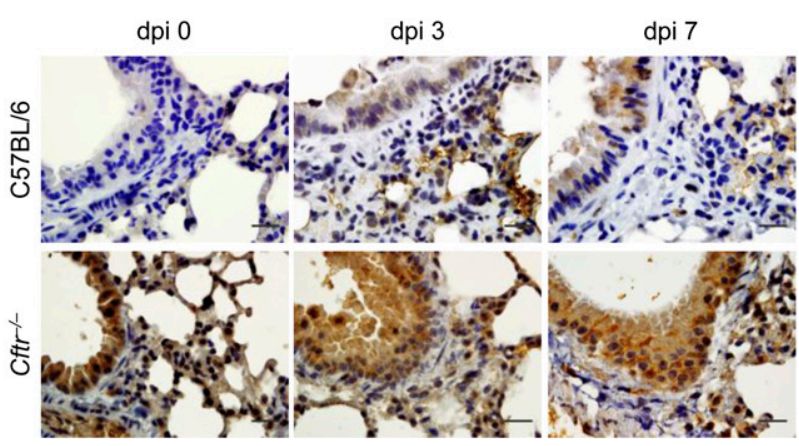

Figure 1. Receptor for advanced glycation end products (RAGE) and S100B expression are up-regulated in cystic fibrosis mice. $\mathrm{C} 57 \mathrm{BL} / 6 \mathrm{or} \mathrm{Cftr}^{-1-}$ mice were infected intranasally with live Aspergillus fumigatus 293 conidia and assessed for $(A)$ RAGE expression by immunofluorescence staining of lung, $(B)$ reverse transcriptase polymerase chain reaction, and $(C)$ Western blotting of total lung cells at different days postinfection (dpi). In $C$, the three major RAGE isoforms of 57.4, 52.6, and $45.1 \mathrm{kD}$ recognized by N-16 antibody, namely the XRAGE, likely an additional form of membrane RAGE, the "full-length" transmembrane isoform (mRAGE), and a soluble (sRAGE) isoform are shown. (D) ERK p42/p44 activation, (E) canonicalnoncanonical nuclear factor-kB activation, and $(F)$ p38 phosphorylation in total lung cells from infected mice at different dpi. (G) Hmgb1 and S100b gene expression by reverse transcriptase polymerase chain reaction. $(H)$ High-mobility group box 1 (HMGB1) protein levels by Western blotting. (I) S100B immunohistochemistry staining in the lungs. Photographs were taken using a high-resolution Microscopy Olympus DP71 using a $\times 20$ objective for RAGE (scale bars $=200 \mu \mathrm{m}$ ) and a $\times 100$ objective for S100B (scale bars $=20 \mu \mathrm{m}$ ). For immunostaining, lung sections were incubated overnight with anti-S100B or anti-RAGE antibody followed by the secondary antibodies. Shown are representative images out of two independent experiments and corresponding pixel density ratio (on naive C57BL/6) normalized against $\beta$-tubulin or total proteins. Scanning densitometry was done on a Scion Image apparatus. Values represent the mean \pm SD of six mice per group and are representative of three experiments. ${ }^{*} P<0.05$; ${ }_{* *} P<0.01$, Student $t$ test. CFTR $=$ cystic fibrosis transmembrane conductance regulator.

(GenBank: M59486) and murine (GenBank: NC_000076.5) S100b (37). Consistently, we have shown that $S 100 \mathrm{~b}$ expression in airway epithelial cells is transcriptionally regulated by the sequential action of downstream MyD88- and TRIF-dependent NF-kB signaling pathways. It was induced by canonical NF-кB downstream the TLR2/MyD88/ERK pathway and inhibited by noncanonical NF- $\mathrm{B}$ downstream TLR3/TRIF/p38 (37). Thus, because TLR2 signaling (52) and NF- $\mathrm{KB}$-dependent gene products are increased 
A dpi 0
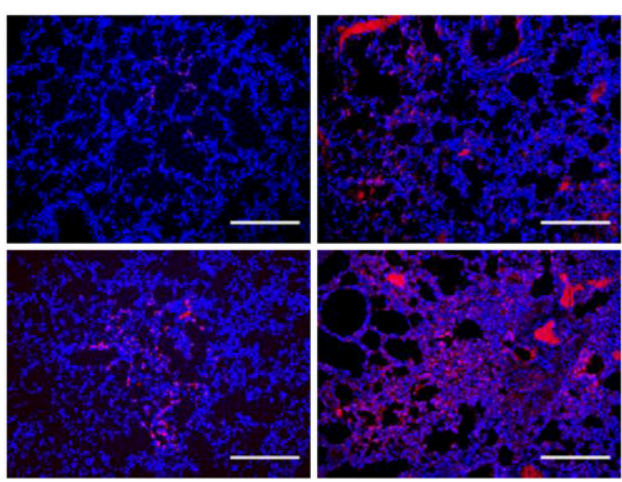

B
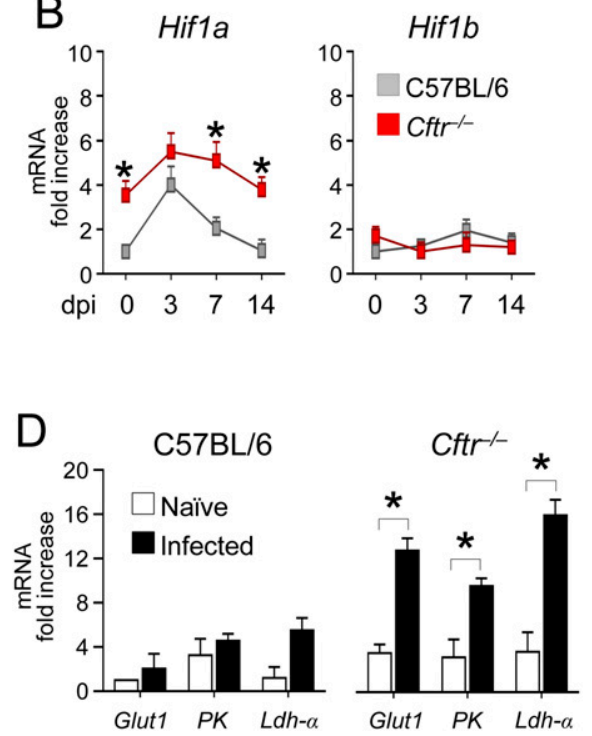

dpi 7
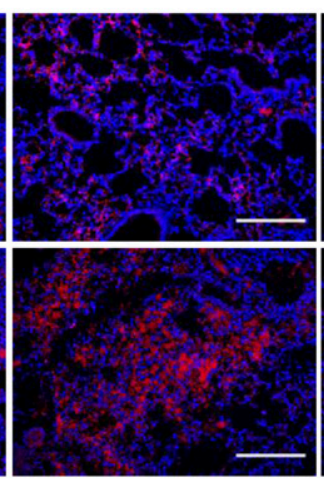

C

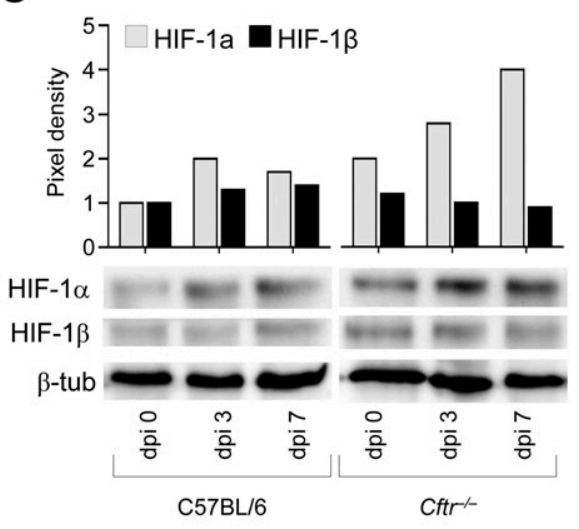

dpi 14
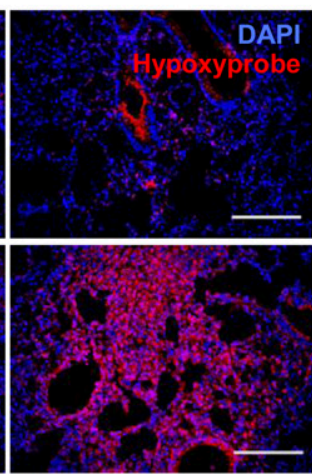

resentative images out of two independent experiments and corresponding pixel density ratio (on naive $\mathrm{C} 57 \mathrm{BL} / 6$ ) normalized against $\beta$-tubulin. (D) Expression of HIF-1 $\alpha$-dependent genes, Glut1 (the transporters glucose transport 1), $P K$ (pyruvate kinase), and $L D H-\alpha$ (lactate dehydrogenase) by RT-PCR at 7 dpi. Photographs were taken using a high-resolution Microscopy Olympus DP71 using a $\times 20$ objective. Scale bars $=200 \mu \mathrm{m}$. Note the increased hypoxia in uninfected cystic fibrosis mice and in lesions (red) during infection. Values represent the mean \pm SD of six mice per group and are pooled data from three (RT-PCR) or representative of two (immunofluorescence and immunoblotting) experiments. ${ }^{*} P<0.05$, Student $t$ test. CFTR $=$ cystic fibrosis transmembrane conductance regulator.
$(3,5)$, whereas the TLR3-TRIF pathway (53) and TRIF-dependent gene products $(3,5)$ are decreased in $\mathrm{CF}$, increased S100B levels are likely to occur in this disease. We evaluated the effects of TLR2 or TLR3 stimulation on the expression of S100B in the lungs of CF mice treated with selective agonists alone or together, namely MALP2 and Poly(I:C). Given the feed-forward RAGE activation by RAGE ligands (54) we also evaluated RAGE expression. S100B and RAGE proteins and genes expression were increased in both WT and CF mice on TLR2 stimulation (Figures 4A and 4B). However, at variance with WT mice, S100B-RAGE expression was also increased in CF mice on concomitant TLR3 stimulation (Figure 4A) and was associated with up-regulated $S 100 \mathrm{~b}$ gene expression (Figure 4B). These data, combined with those of Figures $1 \mathrm{D}-1 \mathrm{~F}$ showing the increased ERK phosphorylation but decreased p38 phosphorylation in CF mice, suggest that increased TLR2-ERK signaling and defective TLR3-p38 signaling both contribute to the increased and sustained expression of S100B in CF. This may imply that respiratory fungal pathogens, through a different capacity to stimulate the different TLRs, may differently impact the S100B-RAGE expression in the lung of CF mice. This seemed to be the case, because different species of Aspergillus, such as nidulans and terreus, both found in patients with CF (35), showed differences in their ability to stimulate S100B and RAGE expression in the lung. At variance with $A$. fumigatus, neither $A s$ pergillus species stimulated S100B and RAGE protein (Figure 4A) or gene (Figure 4C) expression in either WT or CF mice. We next assessed whether and how hypoxia adaptation may contribute to the ability of fungi to activate the S100B-RAGE axis.
To this purpose, we evaluated the impact on S100B-RAGE expression of a mutant strain of $A$. fumigatus unable to grow in hypoxic conditions (41). We found that the S100B-RAGE expression induced by the mutant strain was lower as compared with the WT strain in the lung of CF and WT mice (Figures 4A-4C), a finding indicating that the failure to adapt to hypoxia may restrain the activation of the S100B-RAGE axis in infection. Therefore, pathogen recognition, and likely metabolic activity, contributes to the activation of the S100B-RAGE pathway in the $\mathrm{CF}$ lung by fungi.

\section{Targeting RAGE Has Curative Effects in Murine CF}

Given the above findings, we tested the efficacy of treatments aimed at inhibiting RAGE activity in murine CF by means of administration of sRAGE to $\mathrm{Cftr}^{-1-}$ mice with aspergillosis. In preliminary experiments we found that, despite the important immunomodulatory activity exhibited by sRAGE given intraperitoneally (55), local delivery of purified mouse sRAGE by means of intranasal administration had superior activity in WT mice (data not shown). We therefore subjected WT and CF mice to repeated (five times) intranasal administration of $20 \mu \mathrm{g}$ of sRAGE, totaling a dose exceeding the concentration $(\sim 75 \mu \mathrm{g})$ of sRAGE found in a mouse lung (56). Mice were infected with A. fumigatus and then evaluated for parameters of infection and inflammation. We found that the treatment restricted the fungal growth (Figure 5A), reverted tissue inflammation (Figure 5B), decreased IL-17A and IL-4 production, and increased IL-10 in $\mathrm{Cftr}^{-/-}$mice (Figure 5C). Lung immunostaining revealed 
A
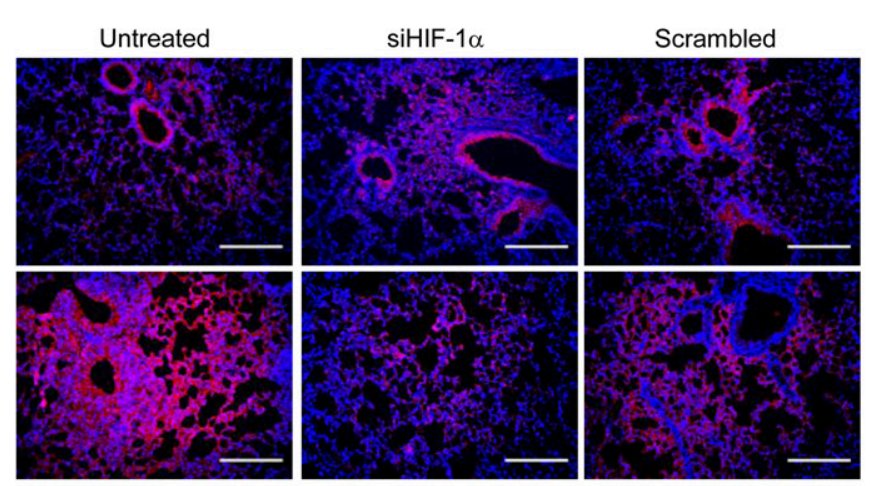

B

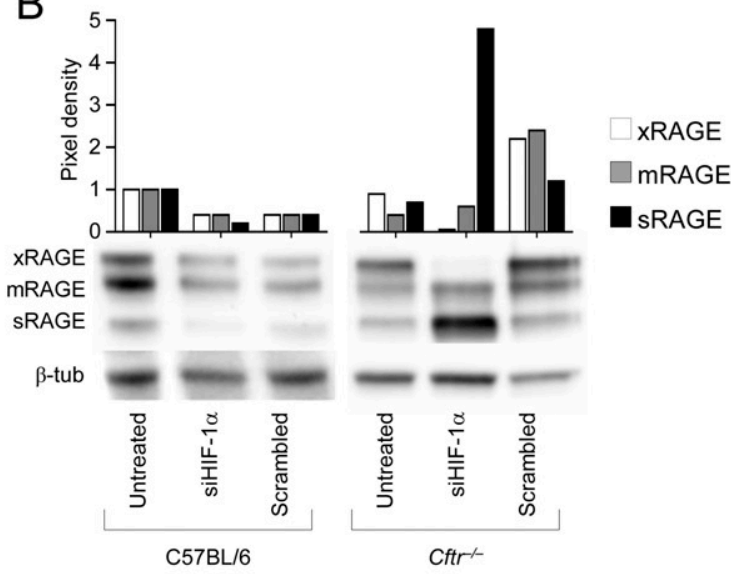

C
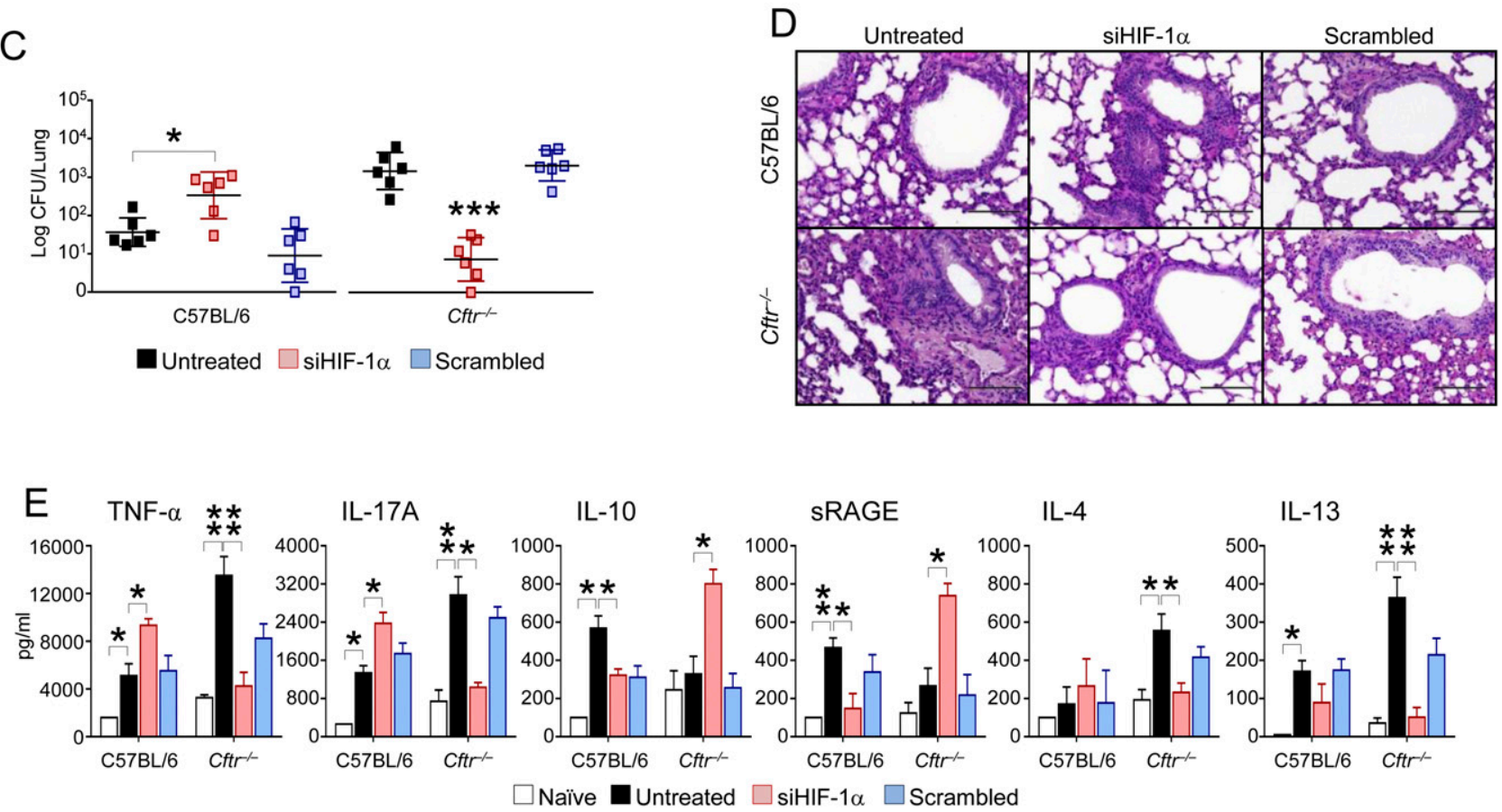

$\mathrm{IL}-4$
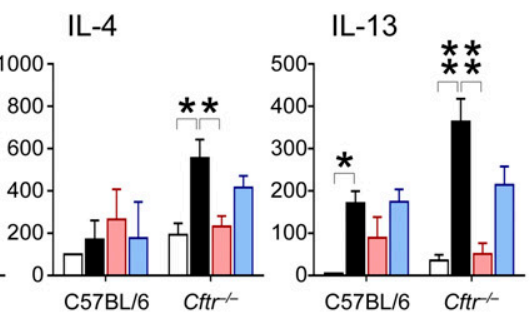

Figure 3. Hypoxia regulates receptor for advanced glycation end products (RAGE) expression in cystic fibrosis mice. C57BL/6 or $\mathrm{Cftr}^{-/-} \mathrm{mice}^{-}$were infected intranasally with live Aspergillus fumigatus 293 conidia, treated with hypoxia inducible factor (HIF)-1 $\alpha$ siRNA or scrambled siRNA, and assessed for $(A)$ RAGE expression in the lungs by immunofluorescence staining, $(B)$ Western blotting of the three major isoforms, $(C)$ fungal growth (mean value log cfu) in the lungs, (D) lung histology (periodic acid-Schiff staining), and (E) cytokine levels (ELISA, mean value) in total lung homogenates. Assays were done at 7 days postinfection. Photographs were taken using a high-resolution Microscopy Olympus DP71 using a $\times 40$ objective. Scale bars $=100 \mu \mathrm{m}$. Shown in $B$ are representative blots out of two independent experiments and corresponding pixel density ratio (on untreated C57BL/6) normalized against $\beta$-tubulin. Values represent the mean \pm SD of six mice per group and are pooled data from three (reverse transcriptase polymerase chain reaction) or representative of two (immunofluorescence and histology) experiments. ${ }^{*} P<0.05$; ${ }^{* *} P<0.01$, ${ }^{* * \star} P<$ 0.001 , one-way analysis of variance Bonferroni post-test. CFTR $=$ cystic fibrosis transmembrane conductance regulator; $s$ RAGE $=$ soluble RAGE; $\mathrm{TNF}=$ tumor necrosis factor.

that treatment with sRAGE also decreased the local expression of S100B (Figure 5D) and, most importantly, of RAGE (Figure $5 \mathrm{E})$. Thus, these findings indicate that sRAGE, by preventing S100B from binding to RAGE, may prevent excessive inflammation promoted by feed-forward RAGE activation (37). In contrast, consistent with the ability of the S100B-RAGE axis to restrain pathogen-induced inflammation in physiologic conditions (37) and, more generally, with the multiple roles played by RAGE in executing the signal transduction mechanisms initiated by ligand binding (57), treatment with sRAGE, while decreasing the local fungal growth (Figure 5A), failed to ameliorate lung inflammation (Figure 5B) and to affect the IL-17A/ IL-4/IL-10 production in WT mice (Figure 5C).

\section{RAGE and S100B Expressions Are Up-regulated in CF Mice with Pseudomonas aeruginosa Infection}

To provide evidence that the sustained activation of the HIF-1 $\alpha-$ RAGE pathway in CF also occurs in infection by the most common CF pathogen, $P$. aeruginosa, we analyzed the expression of HIF-1 subunits, S100B, and RAGE in the lung of WT and CF mice with chronic $P$. aeruginosa infection. We found that, associated with an higher bacterial burden (Figure 6A), the expression of HIF-1 $\alpha$ gene (Figure 6B) and protein (Figure 6C), S100B, and RAGE protein by immunofluorescence (Figure 6D) and Western blotting (Figure $6 \mathrm{E}$ ) and gene by reverse transcriptase polymerase chain reaction (Figure $6 \mathrm{~F}$ ) were all increased in infected $\mathrm{CF}$ mice. 

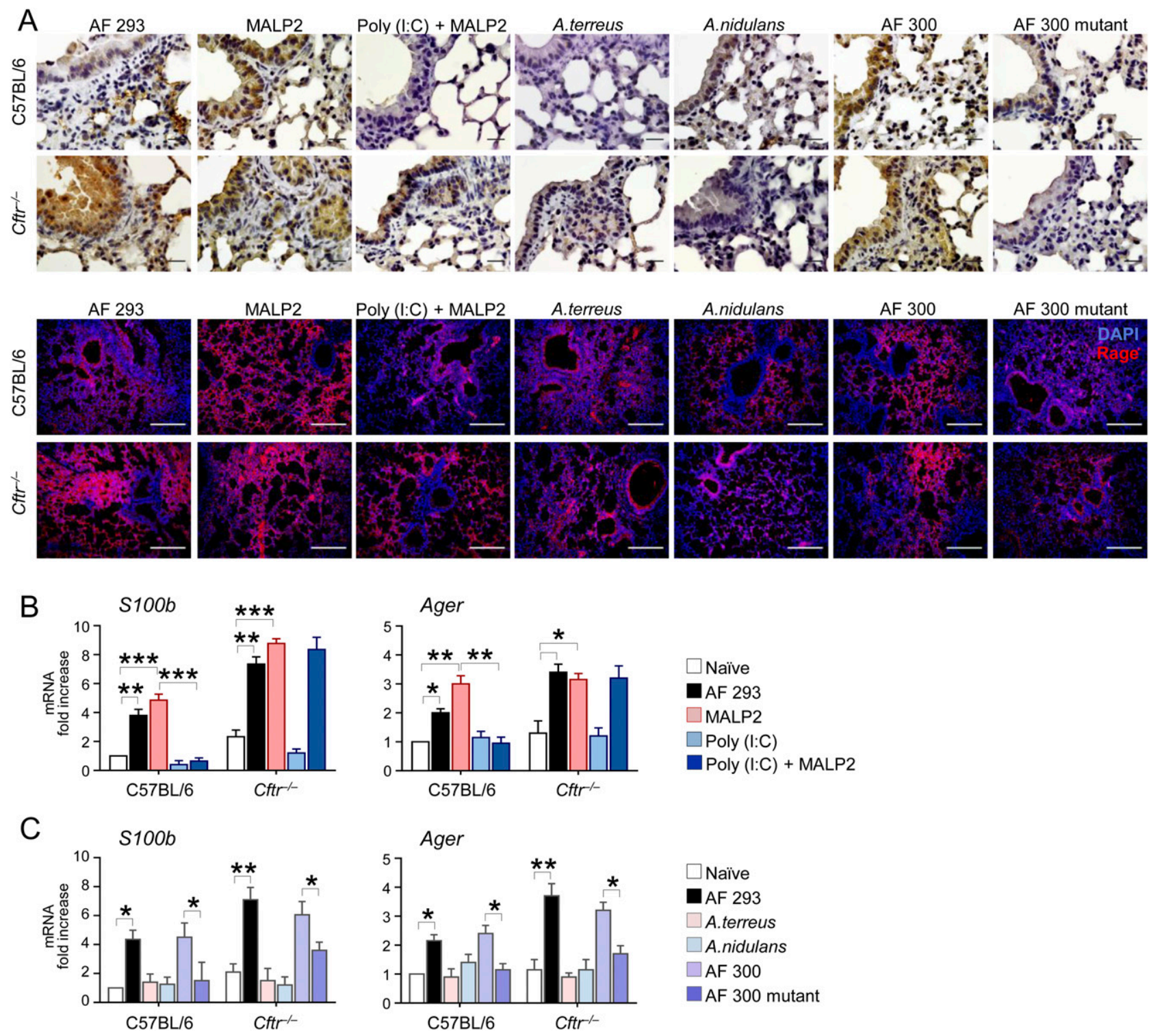

Figure 4. Toll-like receptors contribute to the $\mathrm{S} 100 \mathrm{~B}-$-receptor for advanced glycation end products (RAGE) up-regulated expression in cystic fibrosis mice. C57BL/6 or $\mathrm{Cftr}^{-1-}$ mice were infected intranasally with live condia of Aspergillus fumigatus strains 293, 300, the 300 mutant, A. nidulans, and A. terreus or treated with MALP2 or Poly (I:C) intranasally. $(A)$ Expression of S100B and RAGE by immunohistochemistry and immunofluorescence staining, respectively, at 3 days postinfection. Photographs were taken using a high-resolution Microscopy Olympus DP71 using a $\times 20$ objective for RAGE (scale bars $=200 \mu \mathrm{m})$ and a $\times 100$ objective for S100B (scale bars $=20 \mu \mathrm{m}) .(B$ and $C$ ) Expression of S100b and Ager gene by reverse transcriptase polymerase chain reaction on total lung cells at 3 days postinfection. Values represent the mean \pm SD of six mice per group and are pooled data (reverse transcriptase polymerase chain reaction) or representative (immunofluorescence and histology) of two experiments. ${ }^{*}<0.05$; ${ }^{* *} P<0.01,{ }^{* * *} P<0.001$, one-way analysis of variance Bonferroni post-test. CFTR $=$ cystic fibrosis transmembrane conductance regulator.

Even in this infection, sRAGE could be detected in WT mice 2 weeks after the infection but not in $\mathrm{CF}$ mice (Figure 6E) and administration of sRAGE greatly reduced the bacterial burden (Figure 6A) and RAGE expression (Figure 6B) in CF mice. These data suggest that the S100B-RAGE axis is up-regulated in $P$. aeruginosa infection in CF mice and are fully consistent with the up-regulated expression of TLR2 (58) and impaired expression of TLR3 (53) observed in this infection.

\section{RAGE and S100B Are Up-regulated in Human CF}

To assess whether RAGE was up-regulated in human CF by hypoxia, we evaluated protein expression in bronchial epithelial cells (HBE) from a patient with CF (7) on 4-hour exposure to A. fumigatus conidia, S100B, or HMGB1 in hypoxic or normoxic conditions. Immunofluorescence staining revealed that RAGE expression was detected in CF-HBE kept at normoxic conditions (Figure 7A), either untreated or in response to the different stimuli. However, RAGE expression markedly increased in these cells in hypoxic conditions in response to S100B and, to a lower degree, to conidia or HMGB1 (Figure 7B). The number of cells expressing RAGE also increased in CF-HBE on stimulation in normoxic (Figure 7C) or hypoxic (Figure 7D) conditions. Therefore, RAGE expression in human $\mathrm{CF}$ is sensitive to hypoxia and induced by $\mathrm{S} 100 \mathrm{~B}$. In patients with $\mathrm{CF}, A G E R$ expression was up-regulated in lung cells (Figure 7E), sRAGE levels reduced (Figure 7F), and S100B levels increased (Figure 7G) in expectorates, these findings suggesting hyperactivation of the S100BRAGE axis and the relative failure to produce sRAGE in these patients. 
A

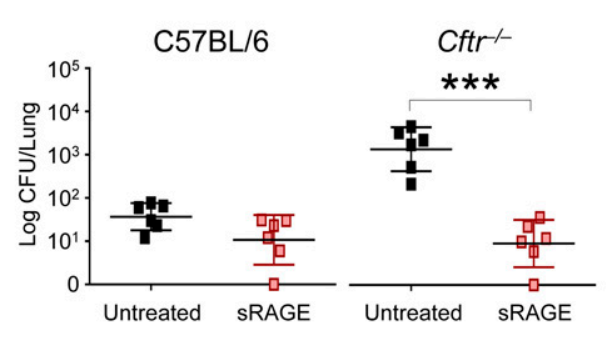

B

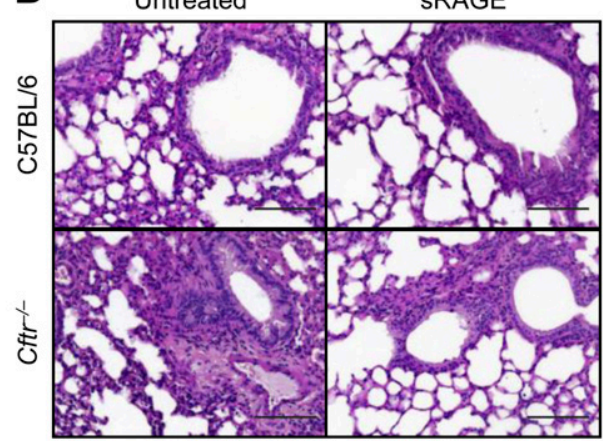

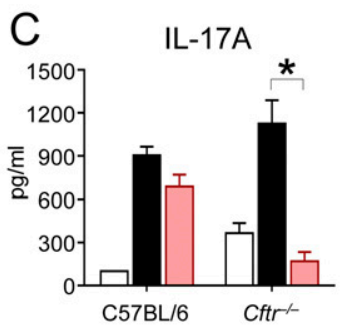

D

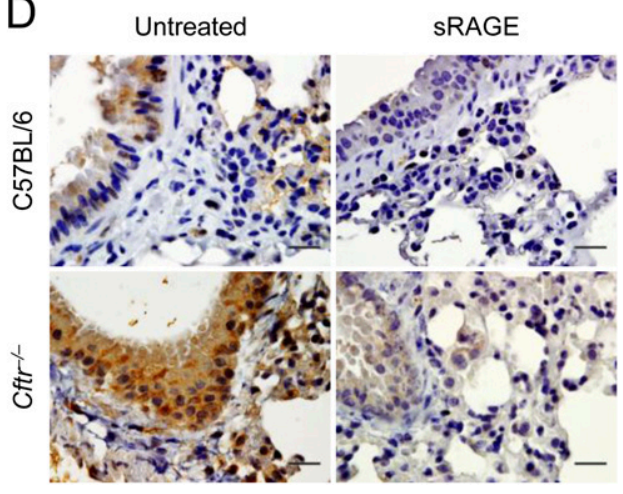

IL-4

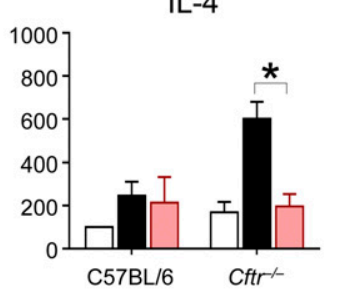

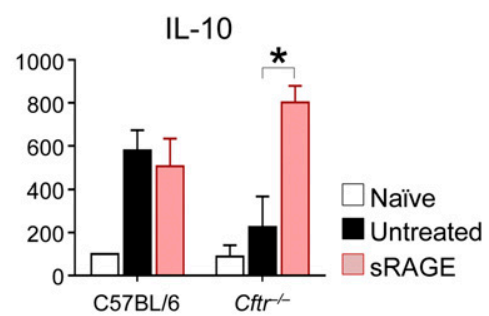

E

SRAGE
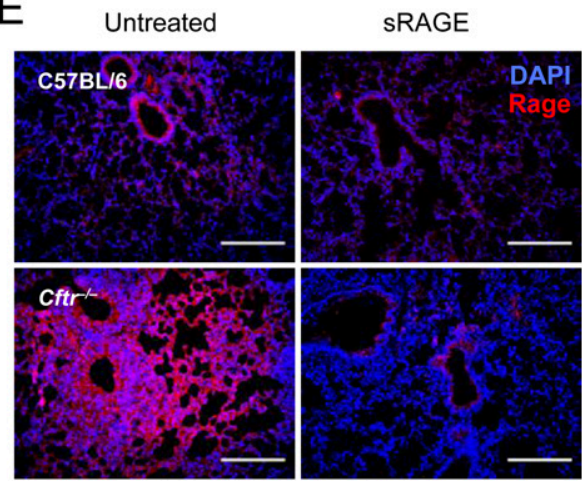

Figure 5. Treatment with soluble receptor for advanced glycation end products (sRAGE) restrains inflammation in cystic fibrosis mice. C57BL/6 or $\mathrm{Cftr}^{-1-}$ mice were infected intranasally with live Aspergillus fumigatus 293 conidia and treated with SRAGE intranasally before the assessment at 7 days postinfection of $(A)$ fungal growth (mean value log $\mathrm{cfu}$ ), (B) lung histology (periodic acid-Schiff staining), (C) cytokine levels (ELISA, mean value) in total lung homogenates, and (D) S100B and (E) RAGE protein expression by immunohistochemistry or immunofluorescence staining, respectively. Photographs were taken using a high-resolution Microscopy Olympus DP71 using a $\times 40$ objective. Scale bars $=$ $100 \mu \mathrm{m}$. Immunohistochemistry or immunofluorescence images were taken using a high-resolution Microscopy Olympus DP71 using a $\times 20$ objective for RAGE (scale bars $=200 \mu \mathrm{m}$ ) and a $\times 100 \mathrm{ob}$ jective for S100B (scale bars $=20 \mu \mathrm{m}$ ). Values represent the mean \pm SD of three mice per group and are pooled (cfu and ELISA) or representative of three experiments. ${ }^{*} P<0.05,{ }^{* * *} P<0.001$, Student $t$ test and one-way analysis of variance Bonferroni post-test. CFTR = cystic fibrosis transmembrane conductance regulator.
It is known that $A G E R$ is a modifier gene of lung disease severity in CF. Indeed, the $A G E R-429 \mathrm{~T} / \mathrm{C}$ polymorphism was associated with an increased lung disease severity in CF and was able to modulate RAGE expression in vitro (26). We assessed whether the $A G E R-374 \mathrm{~T} / \mathrm{A}$ polymorphism, known to lead to an overexpression phenotype (59) and associated with susceptibility to aspergillosis in stem cell transplant recipients (38), might be correlated with lung inflammation in CF (Table 1). $A G E R$ expression was not only up-regulated in patients with $\mathrm{CF}$ bearing the $A G E R-374 \mathrm{~T} / \mathrm{A}$ polymorphism (Figure $7 \mathrm{E}$ ) but also contributed to higher levels of $\mathrm{IgE}$ (Figure $7 \mathrm{H}$ ) in both patients with atopy and ABPA-sensitized patients (see Figure E2) independently from the type of $\Delta F 508$ mutation (data not shown), a finding indicating that RAGE hyperactivation may contribute to lung allergic inflammation in human CF that may eventually facilitate sensitization by Aspergillus spp.

\section{DISCUSSION}

In the present study, we used in vivo and in vitro models to show that sustained expression of RAGE and its ligand S100B exerted a proximal role in the chronic inflammatory state in $\mathrm{CF}$, such that targeting the RAGE pathway in vivo restored lung immune homeostasis and measurement of sRAGE levels could be a useful biomarker for RAGE-related pathogenic inflammation in patients with CF. Thus, our study expands on previous findings showing that RAGE expression is up-regulated on CF airways neutrophils (4) and contributes to disease severity $(25,26)$. This is consistent with the opposing role of RAGE signaling in acute inflammation, where it stimulates host's proinflammatory events and in conditions of persistent elevations of endogenous ligands where it promotes chronic pathogenic inflammation $(29,37)$. Additionally, we provide evidence for the contribution of hypoxia and TLRs to the sustained activation of this inflammatory pathway, being RAGE up-regulated by hypoxia and S100B by infection by TLRs. This may represent a unifying conceptual framework within which to accommodate the vicious cycle of airways infection and inflammation in $\mathrm{CF}$. Because RAGE down-regulates neutrophil survival and functions in murine aspergillosis (37), this may explain the seemingly apparent paradox of failure to eliminate pathogen in the face of an heightened inflammatory response in CF. Additionally, the activation of the Th17 pathway downstream RAGE (37) may further impair through a positive feed-back loop the host's antimicrobial resistance by increasing RAGE expression (60) and promoting fungal growth and virulence in a host-autonomous fashion (61). As a matter of fact, we have already shown that treatments with IL-17A antagonists restored lung immune homeostasis and antimicrobial resistance in experimental CF (7).

Our study shows that, in addition to HMGB1, whose levels are significantly elevated in bronchoalveolar lavage fluids of patients with CF (62), S100B also contributes to excessive lung 

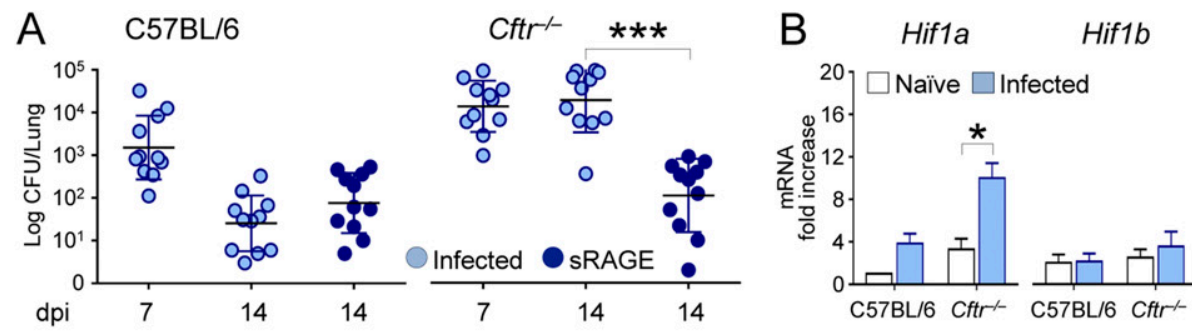

D

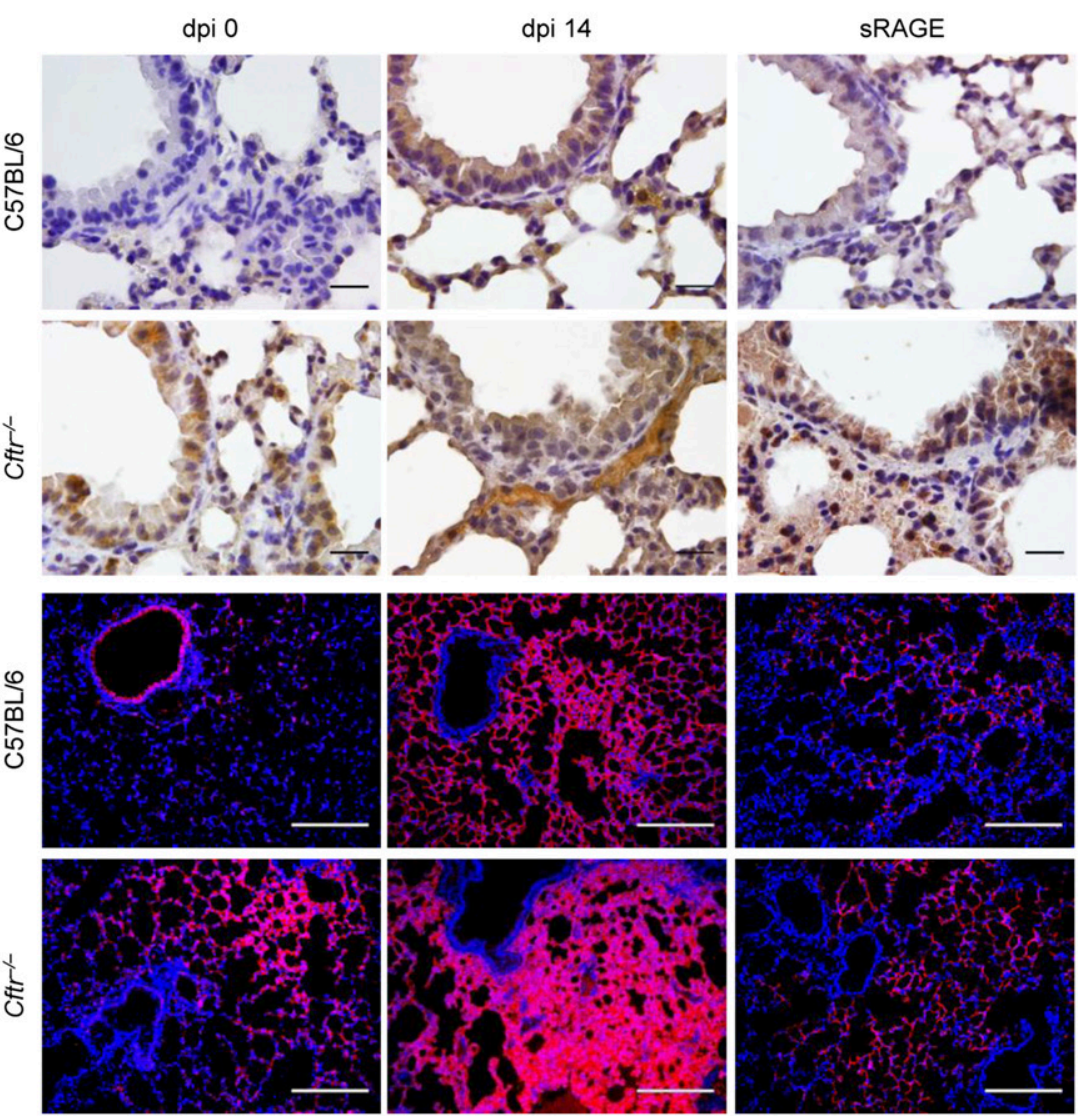

C

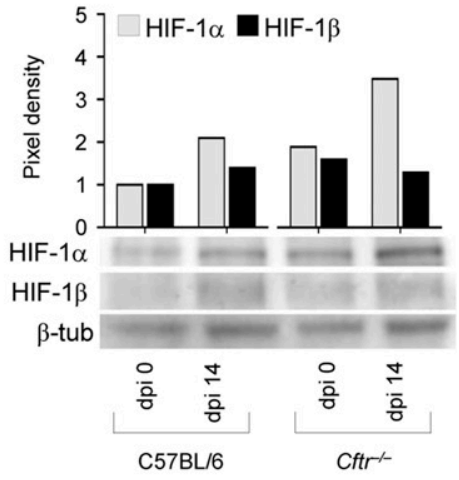

$\mathrm{E}$

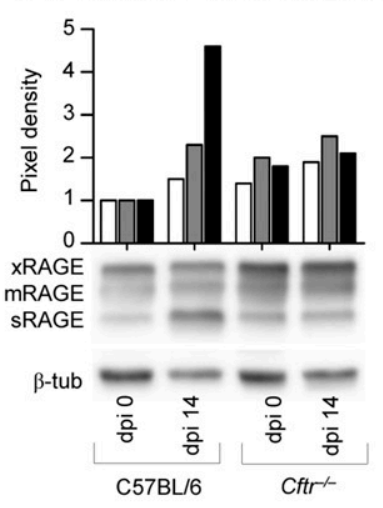

$\mathrm{F}$

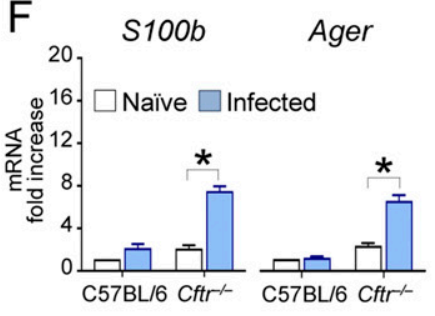

Figure 6. Receptor for advanced glycation end products (RAGE) and S100B expression are up-regulated in Pseudomonas aeruginosa infection. C57BL/6 or $\mathrm{Cftr}^{-/}$mice were intratracheally infected with $5 \times 10^{6} \mathrm{cfu} /$ agar beads of $P$. aeruginosa before the assessment at 7 and 14 days postinfection (dpi) of bacterial burden (dots represent individual measurements of cfu per lung, and horizontal lines represent median values). (A) Hypoxia-inducible factor (HIF)- $1 \alpha$ and HIF-1 $\beta$ gene $(B)$ and protein $(C)$ expression; S100B and RAGE expression by $(D)$ immunofluorescence, $(E)$ Western blotting, and $(F)$ reverse transcriptase polymerase chain reaction on total lung cells. Mice were treated intranasally with $20 \mu \mathrm{g}$ of soluble ( $\mathrm{s}$ ) RAGE every other day, starting the day before and up to13 days after the infection. Photographs were taken using a high-resolution Microscopy Olympus DP71 using a $\times 20$ objective for RAGE (scale bars $=200 \mu \mathrm{m}$ ) and a $\times 100$ objective for S100B (scale bars $=20 \mu \mathrm{m}$ ). Values represent the mean \pm SD of six mice per group and are pooled (cfu and reverse transcriptase polymerase chain reaction) or representative (immunofluorescence) of two experiments. ${ }^{*} P<0.05,{ }^{* \star *} P<0.001$, Student $t$ test and one-way analysis of variance Bonferroni post-test. CFTR $=$ cystic fibrosis transmembrane conductance regulator.

inflammation in $\mathrm{CF}$ during fungal and bacterial pneumonia, likely through feed-forward RAGE activation (37). Elevated levels of S100B have been observed in certain immunomediated diseases (40), a finding also consistent with the ability of S100B to form complexes with TLR ligands, thus affecting the activity of the partner receptor (37). In this regard, through binding to nucleic acids, intracellular S100B was able to activate the TLR3TRIF-dependent pathway that, by transcriptionally down-regulating $S 100 b$ gene expression (37), inhibited the S100B-RAGE axis and contributed to resolution of inflammation in fungal pneumonia. This predicts that TLR3 hypofunctioning, which has been reported in patients with CF (53), may contribute to the degree of inflammation in response to respiratory infections in these patients and suggests that immune screening for TLR3 functional activity would help identify those patients with $\mathrm{CF}$ at risk of developing inflammatory pathology in infections. Although several studies suggested that $\mathrm{CF}$ and non-CF epithelia have similar expression of TLRs $(52,63)$, alterations in receptor localization resulting in different TLR-dependent signaling between epithelial and myeloid cells have been described (5).

One interesting observation of the present study is that, in addition to the up-regulated expression of the S100B-RAGE axis, sRAGE expression and production were down-regulated in murine and human CF. As in various chronic pulmonary diseases (30), sRAGE deficiency was linked to sustained inflammation in murine $\mathrm{CF}$ that could be reversed on SRAGE administration. 

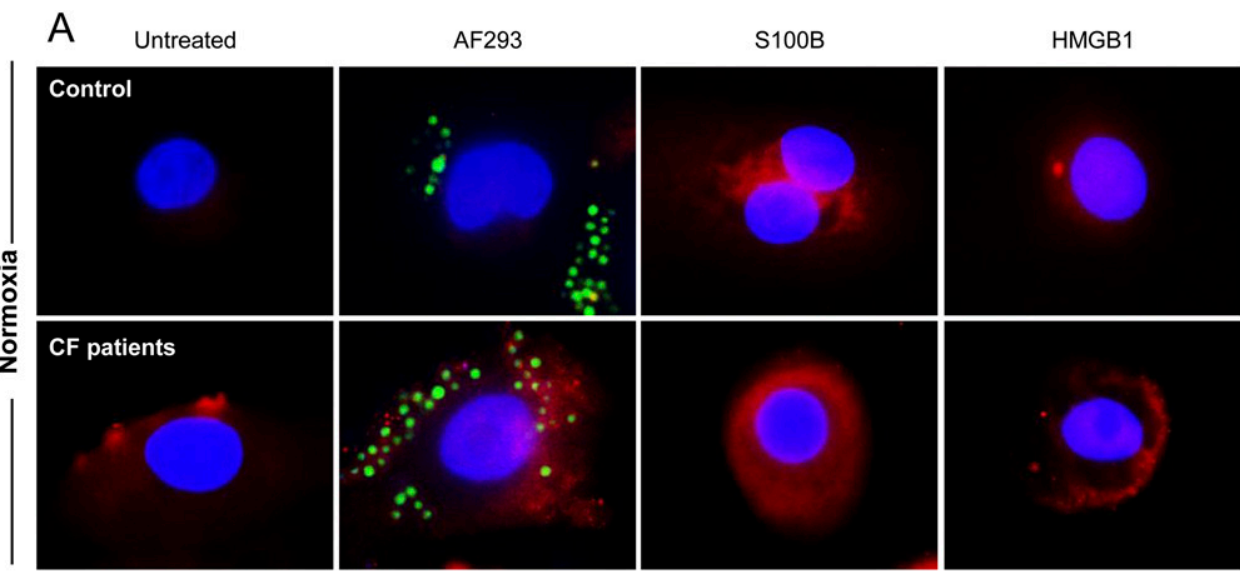

B
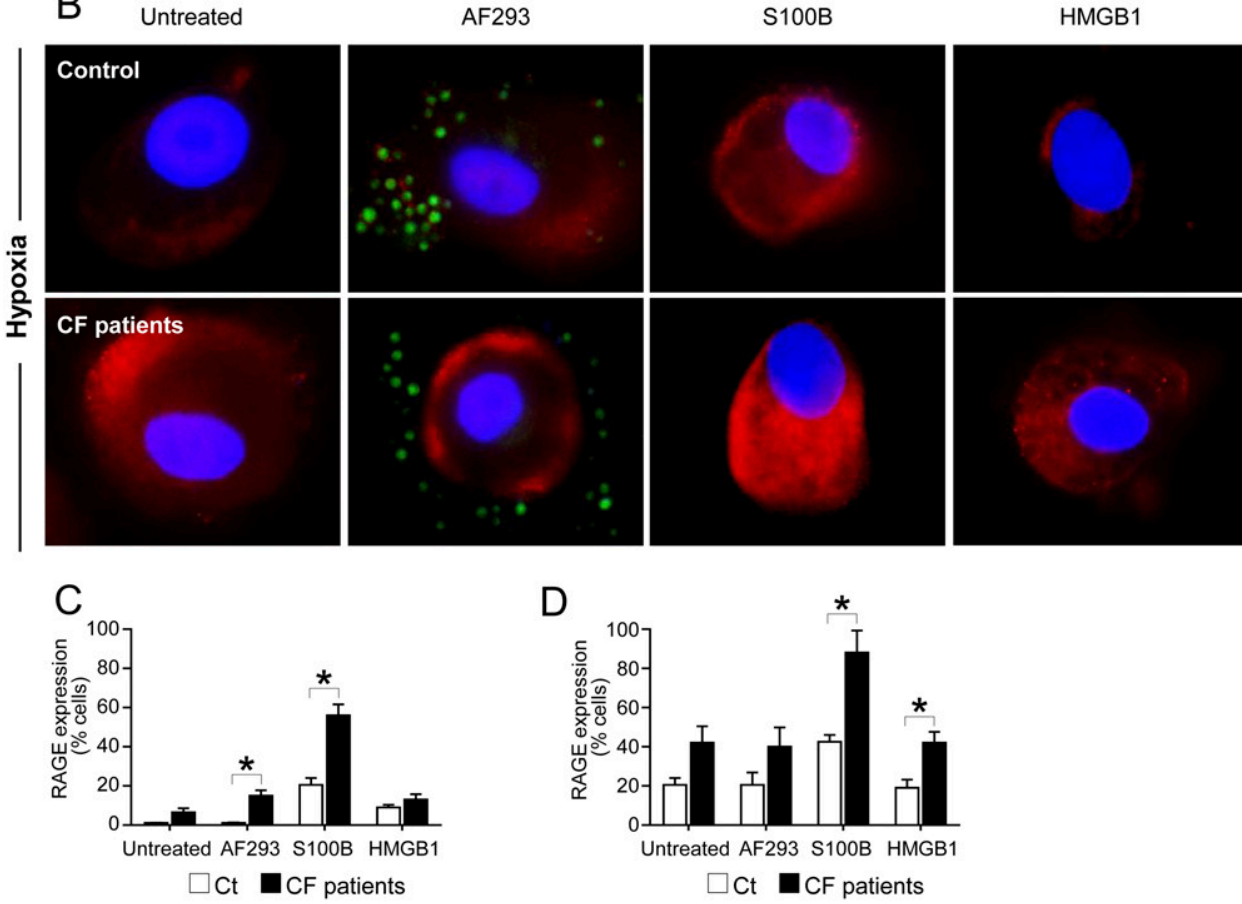

D
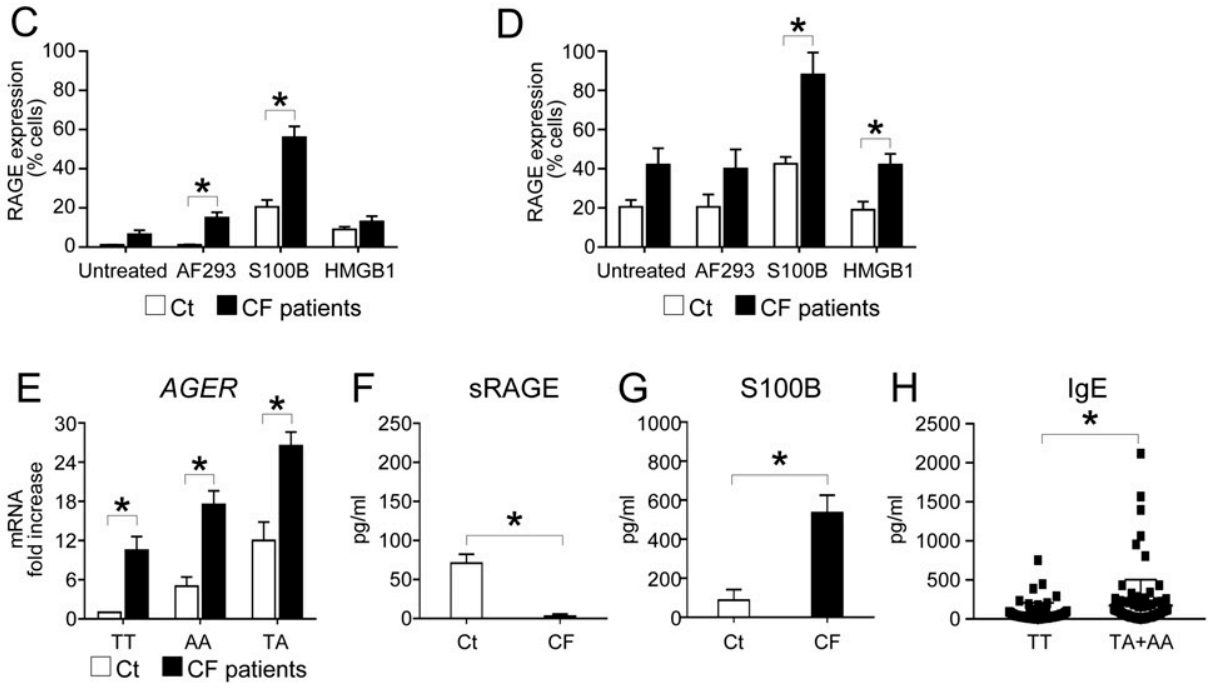

Figure 7. Receptor for advanced glycation end products (RAGE) and S100B are up-regulated in human cystic fibrosis (CF) by hypoxia. ( $A$ and $B$ ) Human bronchial epithelial cells homozygous for SF508 mutation and control (Ct) cells were cultured in normoxic or hypoxic conditions and exposed to Aspergillus fumigatus conidia at cells:fungi ratio of 2:1, $4 \mathrm{nM} \mathrm{S100B}$ or $400 \mu \mathrm{M}$ high-mobility group box 1 (HMGB1). Cells were incubated for 18 hours at $37^{\circ} \mathrm{C}$ in $5 \%$ (normoxic) or $0.05 \% \mathrm{CO}_{2}$. Cultures growing on culture slides were fixed and incubated with anti-RAGE antibody. Images were acquired using the Olympus BX51 fluorescence microscope with a $\times 100$ objective and the analySIS image processing software (Olympus). DAPI was used to detect nuclei. Representative images of two independent experiments from three patients homozygous for $\delta \mathrm{F} 508$ mutation and $\mathrm{Ct}$ cells. (C) Number of human bronchial epithelial cells with positive RAGE expression in normoxic conditions or $(D)$ hypoxic conditions (mean $\pm S D$, determined by fluorescence microscopy) $(n=2)$. ( $(E)$ Cellular $A G E R$ expression by reverse transcriptase polymerase chain reaction, levels of $(F)$ soluble (s) RAGE, $(G)$ S100B, and $(H)$ total $\lg \mathrm{E}$ in expectorates from $\mathrm{Ct}$ or patients with CF carrying the $\Pi$, $T A$, or AA genotypes ( $n=8$ for each genotype) of the AGER -374T/A gene. * $P<0.05$, Student $t$ test.
Thus, similar to what was observed in several experimental models (64), the administration of sRAGE as a ligand decoy may have beneficial effects in reducing chronic inflammatory stresses thereby thwarting tissue injury in patients with $\mathrm{CF}$. Additionally, decreased levels of sRAGE may be useful as a biomarker of ligand-RAGE pathway hyperactivity and inadequate endogenous protective response, thus providing a powerful complement to risk stratification and identifying potential therapeutic targets and/or biomarkers of RAGE activity in $\mathrm{CF}$, as already suggested for other diseases (33).

Understanding the full plethora of RAGE alternative splicing and its regulation will be central to exploiting the therapeutic manipulation of RAGE in human diseases (54). In this regard, we have found that sRAGE production was increased by HIF-1 $\alpha$ inhibition, a finding suggesting that HIF-1 $\alpha$ may not only bind to the RAGE promoter to promote RAGE transcriptional activity (22), but also affects the expression of the different RAGE isoforms. However, how the different RAGE isoforms expression is regulated in humans is poorly understood (65). For sRAGE, putative mechanisms include the actions of ADAMs (a disintegrin and metalloprotease) $(66,67)$ and a naturally occurring splice variant resulting in an "endogenous secretory" form of the soluble receptor (68). Irrespective of the putative mechanisms through which HIF-1 $\alpha$ may regulate sRAGE expression, hypoxia may affect RAGE expression through nontranscriptional mechanisms, including the release of advanced glycation end products activating 
TABLE 1. CLINICAL CHARACTERISTICS OF PATIENTS WITH CYSTIC FIBROSIS

\begin{tabular}{lc}
\hline Characteristics & $\mathrm{N}=277$ \\
\hline Sex, \% male & 46.6 \\
Age, yr & $13.5 \pm 11.0$ \\
FEV $_{1} \%$ predicted & $85.1 \pm 26.4$ \\
FVC, \% predicted & $90.6 \pm 22.1$ \\
Height, cm & $149.9 \pm 23.2$ \\
Weight, kg & $47.8 \pm 18.5$ \\
BMl & $20.3 \pm 3.9$ \\
CFTR mutation, \% & 19.5 \\
$\Delta$ F508 homozygous & 38.6 \\
$\Delta$ F508 heterozygous & 31.1 \\
Other & \\
\hline
\end{tabular}

Definition of abbreviations: BMI = body mass index; CFTR = cystic fibrosis transmembrane conductance regulator.

Continuous variables are expressed as mean \pm SD.

RAGE (69) and the activation of Th17 cells $(16,17)$ promoting RAGE expression (60). In addition, inhibition of IDO protein level and activity under hypoxia (18) may further contribute to up-regulation of Th17 cell response, and hence RAGE activity in CF. Therefore, treatments with IL-17A antagonists or IDO-promoting agents to restore lung immune homeostasis and antimicrobial resistance (7) may also include an activity on RAGE that may further add to their therapeutic activity. Similarly, the protective effects of cyclosporin A in murine CF (7) may not only result from decreased calcineurin activity in lung but also encompass the inhibition of HIF$1 \alpha$ transcriptional activity (70) or a combination of these factors.

The finding that blocking HIF-1 $\alpha$ by siRNA ameliorates inflammation in $\mathrm{CF}$ mice suggests that targeting hypoxia could down-regulate RAGE and Th17 activity and restore IDO function. Of interest, HIF- $1 \alpha$ dimerizes with HIF-1 $\beta$ protein, also known as aryl hydrocarbon nuclear translocator, which is an important binding partner for the aryl hydrocarbon receptor (71), an environment-sensing transcription factor with important immunomodulatory properties in the lung (72). Thus, hypoxia, by decreasing aryl hydrocarbon receptor activity in the lung, may further impact lung inflammation, as suggested by our own preliminary experiments. However, the potential for impairment of essential immune functions by HIF- $1 \alpha$ inhibition has to be carefully evaluated and weighed $(20,73)$. In fact, despite that hypoxia and immune signaling pathways are connected in the lung at a number of levels (74), further investigations are needed to establish a causal relationship between hypoxia and development of pathogenic inflammation in $\mathrm{CF}$, considering that hypoxia is a rather late event in CF lung and that regional, rather than global, hypoxia within the mucous deposits may likely contribute to $P$. aeruginosa metabolic activity (75) and antibiotic resistance in anaerobic conditions (76).

It has been suggested that adaptation to hypoxia may contribute to fungal virulence $(36,77)$ by cell wall assembly $(78)$ and secondary metabolite production $(49,77)$. We have found that, consistent with the finding that a plethora of genes and proteins are transcriptionally and post-transcriptionally regulated by hypoxia on Aspergillus (77), adaptation to hypoxia may contribute to the activation of S100B-RAGE axis in fungal pneumonia. Of interest, we found differences, among different Aspergillus species, in the ability to up-regulate the S100B-RAGE axis, a finding that could help discriminate saprophitic versus nonsaprophitic fungal growth in the lung of patients with $\mathrm{CF}$.

Collectively, we have identified a novel molecular pathway that contributes to the heightened inflammation in CF and provided evidence that this pathway could be a useful therapeutic target and biomarker of lung inflammation in this disease.

\section{References}

1. Cantin A. Cystic fibrosis lung inflammation: early, sustained, and severe. Am J Respir Crit Care Med 1995;151:939-941.

2. Hoffman LR, Ramsey BW. Cystic fibrosis therapeutics: the road ahead. Chest 2013;143:207-213.

3. Hartl D, Gaggar A, Bruscia E, Hector A, Marcos V, Jung A, Greene C, McElvaney G, Mall M, Döring G. Innate immunity in cystic fibrosis lung disease. J Cyst Fibros 2012;11:363-382.

4. Mizgerd JP, Lupa MM, Kogan MS, Warren HB, Kobzik L, Topulos GP. Nuclear factor-kappaB p50 limits inflammation and prevents lung injury during Escherichia coli pneumonia. Am J Respir Crit Care Med 2003;168:810-817.

5. Cohen TS, Prince A. Cystic fibrosis: a mucosal immunodeficiency syndrome. Nat Med 2012;18:509-519.

6. Corvol H, Fitting C, Chadelat K, Jacquot J, Tabary O, Boule M, Cavaillon JM, Clement A. Distinct cytokine production by lung and blood neutrophils from children with cystic fibrosis. Am J Physiol Lung Cell Mol Physiol 2003;284:L997-L1003.

7. Iannitti RG, Carvalho A, Cunha C, De Luca A, Giovannini G, Casagrande A, Zelante T, Vacca C, Fallarino F, Puccetti P, et al. Th17/Treg imbalance in murine cystic fibrosis is linked to indoleamine 2,3-dioxygenase deficiency but corrected by kynurenines. Am J Respir Crit Care Med 2013;187:609-620.

8. Robinson KM, Alcorn JF. T-cell immunotherapy in cystic fibrosis: weighing the risk/reward. Am J Respir Crit Care Med 2013;187:564-566.

9. Legendre C, Mooij MJ, Adams C, O'Gara F. Impaired expression of hypoxiainducible factor- $1 \alpha$ in cystic fibrosis airway epithelial cells: a role for HIF-1 in the pathophysiology of CF? J Cyst Fibros 2011;10:286-290.

10. Elphick HE, Mallory G. Oxygen therapy for cystic fibrosis. Cochrane Database Syst Rev 2013;7:CD003884.

11. Duranton C, Rubera I, Cougnon M, Melis N, Chargui A, Mograbi B, Tauc M. CFTR is involved in the fine tuning of intracellular redox status: physiological implications in cystic fibrosis. Am J Pathol 2012; 181:1367-1377.

12. Semenza GL. HIF-1 and mechanisms of hypoxia sensing. Curr Opin Cell Biol 2001;13:167-171.

13. Shimoda LA, Semenza GL. HIF and the lung: role of hypoxia-inducible factors in pulmonary development and disease. Am J Respir Crit Care Med 2011;183:152-156.

14. Yu AY, Frid MG, Shimoda LA, Wiener CM, Stenmark K, Semenza GL. Temporal, spatial, and oxygen-regulated expression of hypoxia-inducible factor-1 in the lung. Am J Physiol 1998;275:L818-L826.

15. Peyssonaux C, Johnson RS. An unexpected role for hypoxic response: oxygenation and inflammation. Cell Cycle 2004;3:168-171.

16. Dang EV, Barbi J, Yang HY, Jinasena D, Yu H, Zheng Y, Bordman Z, Fu J, Kim Y, Yen HR, et al. Control of T(H)17/T(reg) balance by hypoxia-inducible factor 1. Cell 2011;146:772-784.

17. Shi LZ, Wang R, Huang G, Vogel P, Neale G, Green DR, Chi H. HIF1alphadependent glycolytic pathway orchestrates a metabolic checkpoint for the differentiation of TH17 and Treg cells. J Exp Med 2011;208:1367-1376.

18. Herbert A, Ng H, Jessup W, Kockx M, Cartland S, Thomas SR, Hogg PJ, Wargon $\mathrm{O}$. Hypoxia regulates the production and activity of glucose transporter-1 and indoleamine 2,3-dioxygenase in monocyte-derived endothelial-like cells: possible relevance to infantile haemangioma pathogenesis. Br J Dermatol 2011;164:308-315.

19. Roth A, König $P$, van Zandbergen $G$, Klinger $M$, Hellwig-Bürgel $T$, Däubener W, Bohlmann MK, Rupp J. Hypoxia abrogates antichlamydial properties of IFN- $\gamma$ in human fallopian tube cells in vitro and ex vivo. Proc Natl Acad Sci USA 2010;107:19502-19507.

20. Sica A, Melillo G, Varesio L. Hypoxia: a double-edged sword of immunity. J Mol Med (Berl) 2011;89:657-665.

21. Clambey ET, McNamee EN, Westrich JA, Glover LE, Campbell EL, Jedlicka P, de Zoeten EF, Cambier JC, Stenmark KR, Colgan SP, et al. Hypoxia-inducible factor-1 alpha-dependent induction of FoxP3 drives regulatory T-cell abundance and function during inflammatory hypoxia of the mucosa. Proc Natl Acad Sci USA 2012;109:E2784-E2793.

22. Pichiule P, Chavez JC, Schmidt AM, Vannucci SJ. Hypoxia-inducible factor-1 mediates neuronal expression of the receptor for advanced glycation end products following hypoxia/ischemia. J Biol Chem 2007; 282:36330-36340.

23. Makam M, Diaz D, Laval J, Gernez Y, Conrad CK, Dunn CE, Davies ZA, Moss RB, Herzenberg LA, Herzenberg LA, et al. Activation of 
critical, host-induced, metabolic and stress pathways marks neutrophil entry into cystic fibrosis lungs. Proc Natl Acad Sci USA 2009;106: 5779-5783.

24. Mukherjee TK, Mukhopadhyay S, Hoidal JR. Implication of receptor for advanced glycation end product (RAGE) in pulmonary health and pathophysiology. Respir Physiol Neurobiol 2008;162:210-215.

25. Corvol H, Beucher J, Boëlle PY, Busson PF, Muselet-Charlier C, Clement A, Ratjen F, Grasemann H, Laki J, Palmer CN, et al. Ancestral haplotype 8.1 and lung disease severity in European cystic fibrosis patients. J Cyst Fibros 2012;11:63-67.

26. Beucher J, Boëlle PY, Busson PF, Muselet-Charlier C, Clement A, Corvol H; French C F Modifier Gene Study Investigators. AGER $-429 \mathrm{~T} / \mathrm{C}$ is associated with an increased lung disease severity in cystic fibrosis. PLoS ONE 2012; 7:e41913.

27. Hancock DB, Eijgelsheim M, Wilk JB, Gharib SA, Loehr LR, Marciante KD, Franceschini N, van Durme YM, Chen TH, Barr RG, et al. Metaanalyses of genome-wide association studies identify multiple loci associated with pulmonary function. Nat Genet 2010;42:45-52.

28. Repapi E, Sayers I, Wain LV, Burton PR, Johnson T, Obeidat M, Zhao JH, Ramasamy A, Zhai G, Vitart V, et al.; Wellcome Trust Case Control Consortium; NSHD Respiratory Study Team. Genomewide association study identifies five loci associated with lung function. Nat Genet 2010;42:36-44.

29. Han SH, Kim YH, Mook-Jung I. RAGE: the beneficial and deleterious effects by diverse mechanisms of actions. Mol Cells 2011;31:91-97.

30. Sukkar MB, Wood LG, Tooze M, Simpson JL, McDonald VM, Gibson PG, Wark PA. Soluble RAGE is deficient in neutrophilic asthma and COPD. Eur Respir J 2012;39:721-729.

31. Zhang H, Tasaka S, Shiraishi Y, Fukunaga K, Yamada W, Seki H, Ogawa Y, Miyamoto K, Nakano Y, Hasegawa N, et al. Role of soluble receptor for advanced glycation end products on endotoxininduced lung injury. Am J Respir Crit Care Med 2008;178:356-362.

32. Creagh-Brown BC, Burke-Gaffney A, Evans TW. sRAGE: a useful biomarker in acute lung injury? Crit Care Med 2011;39:589-590.

33. Yamagishi S, Matsui T. Soluble form of a receptor for advanced glycation end products (sRAGE) as a biomarker. Front Biosci (Elite Ed) 2010;2: 1184-1195.

34. Sukkar MB, Ullah MA, Gan WJ, Wark PA, Chung KF, Hughes JM, Armour CL, Phipps S. RAGE: a new frontier in chronic airways disease. Br J Pharmacol 2012;167:1161-1176.

35. Sudfeld CR, Dasenbrook EC, Merz WG, Carroll KC, Boyle MP Prevalence and risk factors for recovery of filamentous fungi in individuals with cystic fibrosis. J Cyst Fibros 2010;9:110-116.

36. Wezensky SJ, Cramer RA Jr. Implications of hypoxic microenvironments during invasive aspergillosis. Med Mycol 2011;49:S120-S124.

37. Sorci G, Giovannini G, Riuzzi F, Bonifazi P, Zelante T, Zagarella S, Bistoni F, Donato R, Romani L. The danger signal S100B integrates pathogen- and danger-sensing pathways to restrain inflammation. PLoS Pathog 2011;7:e1001315.

38. Cunha C, Giovannini G, Pierini A, Bell AS, Sorci G, Riuzzi F, Donato R, Rodrigues F, Velardi A, Aversa F, et al. Genetically-determined hyperfunction of the S100B/RAGE axis is a risk factor for aspergillosis in stem cell transplant recipients. PLoS ONE 2011;6:e27962.

39. Legendre C, Reen FJ, Mooij MJ, McGlacken GP, Adams C, O'Gara F. Pseudomonas aeruginosa Alkyl quinolones repress hypoxia-inducible factor 1 (HIF-1) signaling through HIF-1 $\alpha$ degradation. Infect Immun 2012;80:3985-3992.

40. Donato R, Sorci G, Riuzzi F, Arcuri C, Bianchi R, Brozzi F, Tubaro C, Giambanco I. S100B's double life: intracellular regulator and extracellular signal. Biochim Biophys Acta 2009;1793:1008-1022.

41. Rizzetto L, Giovannini G, Bromley M, Bowyer P, Romani L, Cavalieri D. Strain dependent variation of immune responses to A. fumigatus: definition of pathogenic species. PLOS ONE 2013;8:e56651.

42. Peluso L, de Luca C, Bozza S, Leonardi A, Giovannini G, Lavorgna A, De Rosa G, Mascolo M, Ortega De Luna L, Catania MR, et al. Protection against Pseudomonas aeruginosa lung infection in mice by recombinan OprF-pulsed dendritic cell immunization. BMC Microbiol 2010;10:9.

43. Moalli F, Paroni M, Véliz Rodriguez T, Riva F, Polentarutti N, Bottazzi B, Valentino S, Mantero S, Nebuloni M, Mantovani A, et al. The therapeutic potential of the humoral pattern recognition molecule PTX3 in chronic lung infection caused by Pseudomonas aeruginosa. J Immunol 2011;186:5425-5434.
44. Galietta LJ, Folli C, Marchetti C, Romano L, Carpani D, Conese M, Zegarra-Moran O. Modification of transepithelial ion transport in human cultured bronchial epithelial cells by interferon-gamma. Am J Physiol Lung Cell Mol Physiol 2000;278:L1186-L1194.

45. Gefter JV, Shaufl AL, Fink MP, Delude RL. Comparison of distinct protein isoforms of the receptor for advanced glycation endproducts expressed in murine tissues and cell lines. Cell Tissue Res 2009;337:79-89.

46. Ramsgaard L, Englert JM, Manni ML, Milutinovic PS, Gefter J, Tobolewski J, Crum L, Coudriet GM, Piganelli J, Zamora R, et al. Lack of the receptor for advanced glycation end-products attenuates E. coli pneumonia in mice. PLoS ONE 2011;6:e20132.

47. Yeh CH, Sturgis L, Haidacher J, Zhang XN, Sherwood SJ, Bjercke RJ, Juhasz O, Crow MT, Tilton RG, Denner L. Requirement for p38 and p44/p42 mitogen-activated protein kinases in RAGE-mediated nuclear factor-kappaB transcriptional activation and cytokine secretion. Diabetes 2001;50:1495-1504.

48. Bucciarelli LG, Kaneko M, Ananthakrishnan R, Harja E, Lee LK, Hwang YC, Lerner S, Bakr S, Li Q, Lu Y, et al. Receptor for advanced-glycation end products: key modulator of myocardial ischemic injury. Circulation 2006;113:1226-1234.

49. Grahl N, Puttikamonkul S, Macdonald JM, Gamcsik MP, Ngo LY, Hohl TM, Cramer RA. In vivo hypoxia and a fungal alcohol dehydrogenase influence the pathogenesis of invasive pulmonary aspergillosis. PLoS Pathog 2011;7:e1002145.

50. Lum JJ, Bui T, Gruber M, Gordan JD, DeBerardinis RJ, Covello KL, Simon MC, Thompson CB. The transcription factor HIF-1alpha plays a critical role in the growth factor-dependent regulation of both aerobic and anaerobic glycolysis. Genes Dev 2007;21:1037-1049.

51. Ahmad T, Kumar M, Mabalirajan U, Pattnaik B, Aggarwal S, Singh R, Singh S, Mukerji M, Ghosh B, Agrawal A. Hypoxia response in asthma: differential modulation on inflammation and epithelial injury. Am J Respir Cell Mol Biol 2012;47:1-10.

52. Greene CM, Carroll TP, Smith SG, Taggart CC, Devaney J, Griffin S, O'Neill SJ, McElvaney NG. TLR-induced inflammation in cystic fibrosis and noncystic fibrosis airway epithelial cells. J Immunol 2005;174:1638-1646.

53. Parker D, Cohen TS, Alhede M, Harfenist BS, Martin FJ, Prince A. Induction of type I interferon signaling by Pseudomonas aeruginosa is diminished in cystic fibrosis epithelial cells. Am J Respir Cell Mol Biol 2012;46:6-13.

54. Ramasamy R, Yan SF, Schmidt AM. Advanced glycation endproducts: from precursors to RAGE: round and round we go. Amino Acids 2012;42:1151-1161.

55. Brisslert M, Amu S, Pullerits R. Intra-peritoneal sRAGE treatment induces alterations in cellular distribution of $\mathrm{CD} 19(+), \mathrm{CD} 3(+)$ and Mac-1 (+) cells in lymphoid organs and peritoneal cavity. Cell Tissue Res 2013;351:139-148.

56. Englert JM, Ramsgaard L, Valnickova Z, Enghild JJ, Oury TD. Large scale isolation and purification of soluble RAGE from lung tissue. Protein Expr Purif 2008;61:99-101.

57. Tang D, Kang R, Coyne CB, Zeh HJ, Lotze MT. PAMPs and DAMPs: signal 0 s that spur autophagy and immunity. Immunol Rev 2012;249: $158-175$.

58. Shin HS, Lee JH, Paek SH, Jung YW, Ha UH. Pseudomonas aeruginosadependent upregulation of TLR2 influences host responses to a secondary Staphylococcus aureus infection. Pathog Dis 2013;69:149-156.

59. Hudson BI, Stickland MH, Futers TS, Grant PJ. Effects of novel polymorphisms in the RAGE gene on transcriptional regulation and their association with diabetic retinopathy. Diabetes 2001;50:1505-1511.

60. Heo YJ, Oh HJ, Jung YO, Cho ML, Lee SY, Yu JG, Park MK, Kim HR, Lee SH, Park SH, et al. The expression of the receptor for advanced glycation end-products (RAGE) in RA-FLS is induced by IL-17 via Act-1. Arthritis Res Ther 2011;13:R113.

61. Zelante T, Iannitti RG, De Luca A, Arroyo J, Blanco N, Servillo G, Sanglard D, Reichard U, Palmer GE, Latgè JP, et al. Sensing of mammalian IL-17A regulates fungal adaptation and virulence. Nat Commun 2012;3:683.

62. Entezari M, Weiss DJ, Sitapara R, Whittaker L, Wargo MJ, Li J, Wang $\mathrm{H}$, Yang H, Sharma L, Phan BD, et al. Inhibition of high-mobility group box 1 protein (HMGB1) enhances bacterial clearance and protects against Pseudomonas aeruginosa pneumonia in cystic fibrosis. Mol Med 2012;18:477-485 
63. Muir A, Soong G, Sokol S, Reddy B, Gomez MI, Van Heeckeren A, Prince A. Toll-like receptors in normal and cystic fibrosis airway epithelial cells. Am J Respir Cell Mol Biol 2004;30:777-783.

64. Yan SF, Ramasamy R, Schmidt AM. Soluble RAGE: therapy and biomarker in unraveling the RAGE axis in chronic disease and aging. Biochem Pharmacol 2010;79:1379-1386.

65. Kalea AZ, Schmidt AM, Hudson BI. Alternative splicing of RAGE: roles in biology and disease. Front Biosci (Landmark Ed) 2011;16:2756-2770.

66. Raucci A, Cugusi S, Antonelli A, Barabino SM, Monti L, Bierhaus A, Reiss K, Saftig P, Bianchi ME. A soluble form of the receptor for advanced glycation endproducts (RAGE) is produced by proteolytic cleavage of the membrane-bound form by the sheddase a disintegrin and metalloprotease 10 (ADAM10). FASEB J 2008;22:3716-3727.

67. Metz VV, Kojro E, Rat D, Postina R. Induction of RAGE shedding by activation of $\mathrm{G}$ protein-coupled receptors. PLoS ONE 2012;7: e41823.

68. Yonekura H, Yamamoto Y, Sakurai S, Petrova RG, Abedin MJ, Li H Yasui K, Takeuchi M, Makita Z, Takasawa S, et al. Novel splice variants of the receptor for advanced glycation end-products expressed in human vascular endothelial cells and pericytes, and their putative roles in diabetes-induced vascular injury. Biochem J 2003;370:1097-1109.

69. Chang JS, Wendt T, Qu W, Kong L, Zou YS, Schmidt AM, Yan SF. Oxygen deprivation triggers upregulation of early growth response-1 by the receptor for advanced glycation end products. Circ Res 2008; 102:905-913.

70. Koulmann N, Novel-Chaté V, Peinnequin A, Chapot R, Serrurier B, Simler N, Richard H, Ventura-Clapier R, Bigard X. Cyclosporin A inhibits hypoxia-induced pulmonary hypertension and right ventricle hypertrophy. Am J Respir Crit Care Med 2006;174:699-705.

71. Schults MA, Timmermans L, Godschalk RW, Theys J, Wouters BG, van Schooten FJ, Chiu RK. Diminished carcinogen detoxification is a novel mechanism for hypoxia-inducible factor 1-mediated genetic instability. J Biol Chem 2010;285:14558-14564.

72. Chiba T, Uchi H, Yasukawa F, Furue M. Role of the arylhydrocarbon receptor in lung disease. Int Arch Allergy Immunol 2011;155:129-134.

73. Melillo G. HIF-1: a target for cancer, ischemia and inflammation-too good to be true? Cell Cycle 2004;3:154-155.

74. Schaible B, Schaffer K, Taylor CT. Hypoxia, innate immunity and infection in the lung. Respir Physiol Neurobiol 2010;174:235-243.

75. Worlitzsch D, Tarran R, Ulrich M, Schwab U, Cekici A, Meyer KC, Birrer P, Bellon G, Berger J, Weiss T, et al. Effects of reduced mucus oxygen concentration in airway Pseudomonas infections of cystic fibrosis patients. J Clin Invest 2002;109:317-325.

76. Schaible B, Taylor CT, Schaffer K. Hypoxia increases antibiotic resistance in Pseudomonas aeruginosa through altering the composition of multidrug efflux pumps. Antimicrob Agents Chemother 2012;56:2114-2118.

77. Barker BM, Kroll K, Vödisch M, Mazurie A, Kniemeyer O, Cramer RA. Transcriptomic and proteomic analyses of the Aspergillus fumigatus hypoxia response using an oxygen-controlled fermenter. $B M C$ Genomics 2012;13:62.

78. Shepardson KM, Ngo LY, Aimanianda V, Latgé JP, Barker BM, Blosser SJ, Iwakura Y, Hohl TM, Cramer RA. Hypoxia enhances innate immune activation to Aspergillus fumigatus through cell wall modulation. Microbes Infect 2013;15:259-269. 